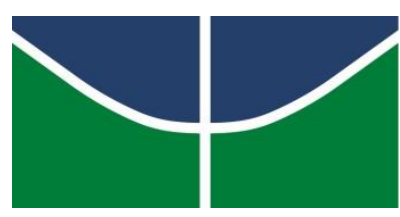

UNIVERSIDADE DE BRASÍLIA

INSTITUTO DE GEOCIÊNCIAS

PÓS-GRADUAÇÃO EM GEOCIÊNCIAS APLICADAS

\title{
RELAÇÕES ENTRE O RELEVO E A ORGANIZAÇÃO ESPACIAL DO USO E COBERTURA DO SOLO NO SUDOESTE DO ESTADO DE GOIÁS
}

TAMIRIS DE ASSIS

Orientador: Prof. Dr. Éder de Souza Martins 


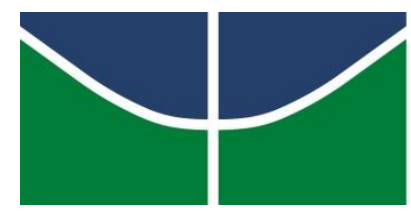

UNIVERSIDADE DE BRASÍLIA

INSTITUTO DE GEOCIÊNCIAS

PÓS- GRADUAÇÃO EM GEOCIÊNCIAS APLICADAS

\section{RELAÇÕES ENTRE O RELEVO E A ORGANIZAÇÃO ESPACIAL DO USO E COBERTURA DO SOLO NO SUDOESTE DO ESTADO DE GOIÁS}

TAMIRIS DE ASSIS

Orientador: Prof. Dr. Éder de Souza Martins

Dissertação de Mestrado apresentada à Banca Examinadora do Instituto de Geociências Aplicadas da Universidade de Brasília, como exigência para obtenção do título de mestra em Geociências Aplicadas.

Área de concentração: Geoprocessamento Aplicado a Análise Ambiental

BRASÍLIA-DF

2016 


\title{
UNIVERSIDADE DE BRASÍLIA \\ Instituto de Geociências
}

\author{
RELAÇÕES ENTRE O RELEVO E A ORGANIZAÇÃO ESPACIAL DO \\ USO E COBERTURA DO SOLO NO SUDOESTE DO ESTADO DE GOIÁS
}

TAMIRIS DE ASSIS

BANCA EXAMINADORA

Éder de Souza Martins (Embrapa/CPAC)

Tati de Almeida (IG/UnB)

Manuel Eduardo Ferreira (IESA/UFG) 
DEDICATÓRIA

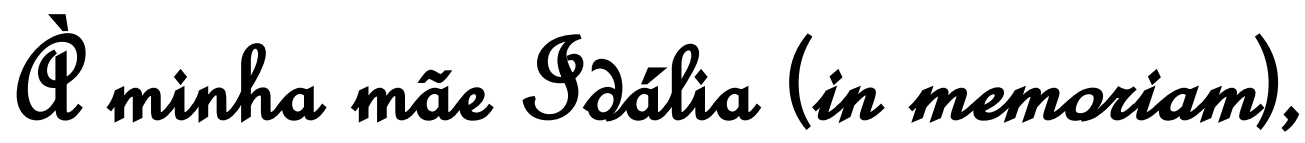
pelo seu amor incondicional. 


\section{AGRADECIMENTOS}

Minha gratidão eterna à minha mãe Idália (in memoriam), pela oportunidade em poder conviver durante esse tempo, por ser meu maior exemplo de vida, mãe e mulher guerreira, que mesmo nos momentos mais difíceis nunca desistiu de lutar pela vida, mas Deus a quis em sua companhia. Também sou grata pelo seu apoio e incentivo para continuar em busca dos meus ideais e por sempre ter estado ao meu lado para ajudar a superar os obstáculos no decorrer do caminho.

Muito obrigada aos meus amigos Vander, Marcia e Lucas que estão ao meu lado tanto nos momentos de alegria, quanto nos momentos de tristeza, demonstrando o verdadeiro significado de amizade. E gratidão aos demais amigos que com palavras de apoio me encorajam a seguir com os meus objetivos de vida.

Aos meus amigos da pós-graduação que em muitos momentos compartilharam suas experiências acadêmicas, técnicas e pessoais que contribuiram em todos os aspectos da minha formação.

Ao Dr. Éder de Souza Martins pelos ensinamentos e pela dedicada orientação, com prestatividade e disponibilidade na construção deste trabalho.

Ao Dr. Antonio Felipe Couto Júnior pelos ensinamentos contínuos do pensamento científico e pela colaboração no desenvolvimento deste trabalho.

Ao Dr. Manuel Eduardo Ferreira e a Dra. Tati de Almeida, por gentilmente aceitarem o convite de participar da banca examinadora desta dissertação, com contribuições de grande relevância para o aprimoramento deste trabalho. 


\section{SUMÁRIO}

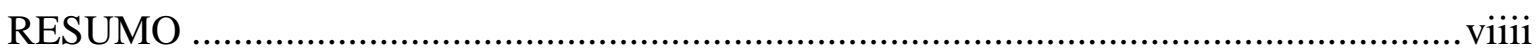

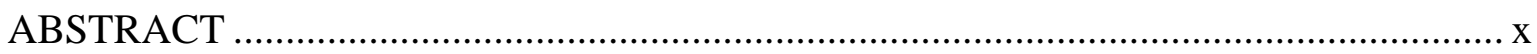

ORGANIZAÇÃO DA DISSERTAÇÃO .......................................................................

CAPÍTULO1 - APRESENTAÇÃO GERAL .............................................................. 1

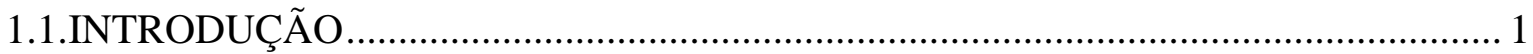

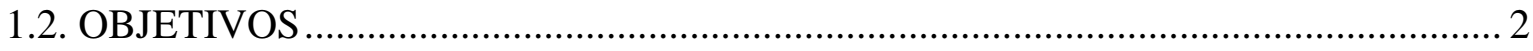

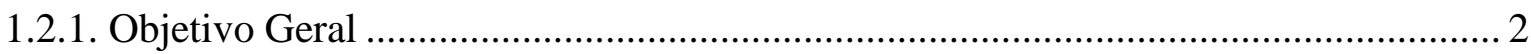

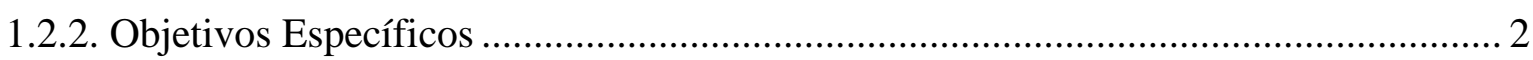

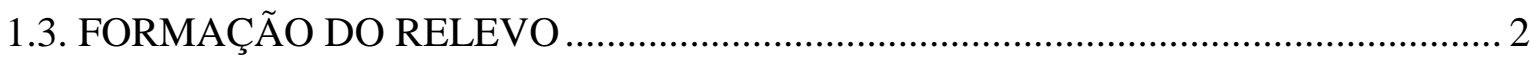

1.4. MAPEAMENTO DAS UNIDADES DE RELEVO .................................................. 5

1.5. MAPEAMENTO DO USO E COBERTURA DA TERRA........................................... 8

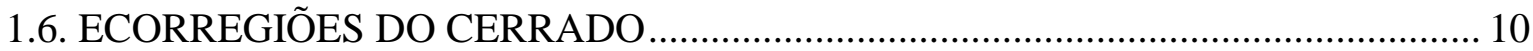

CAPÍTULO 2 - RELAÇÕES ENTRE O RELEVO E A ORGANIZAÇÃO ESPACIAL DO USO E COBERTURA DO SOLO NO SUDOESTE DO ESTADO DE GOIÁS ........ 12

2.1. INTRODUÇÃ

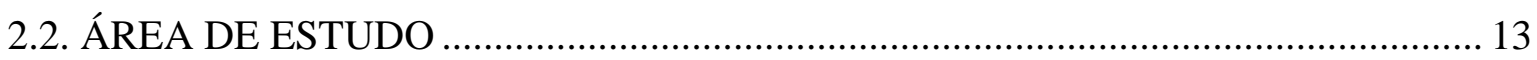

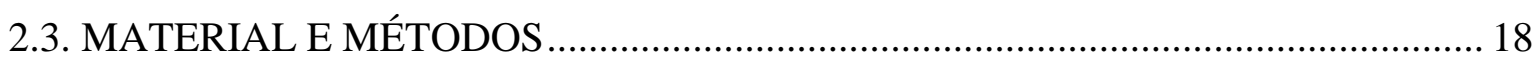

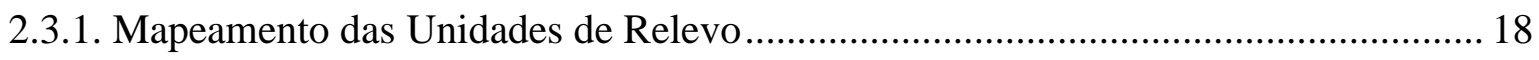

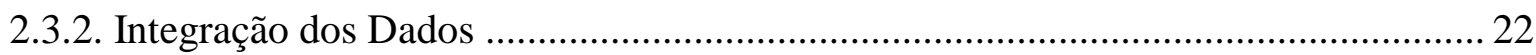

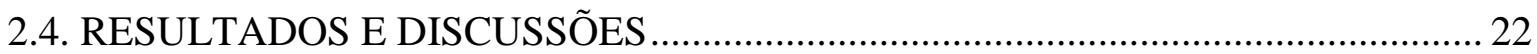

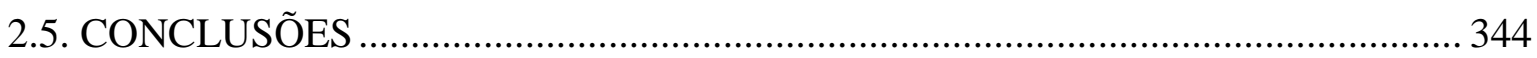

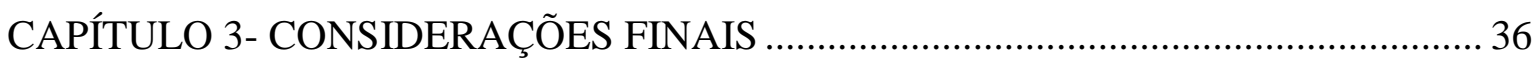

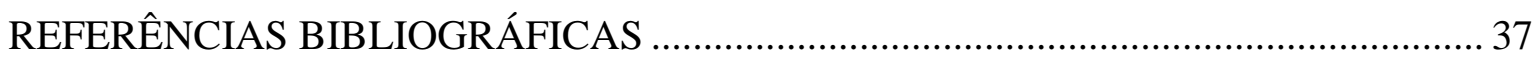




\section{LISTA DE FIGURAS}

Figura 1. Composição Colorida RGB e vetores gerados com base nos padrões de cores da imagem. Fonte: Sena-Souza et al. (2013).

Figura 2. Resultado do mapeamento das unidades geomorfológicas usando a composição colorida para realce das feições das variáveis morfométricas. Fonte: Sena-Souza et al. (2013).

Figura 3. Nomenclatura das unidades de relevo. Fonte: Adaptado de IBGE (2009). 7

Figura 4. Esquema teórico de construção de uma nomenclatura da cobertura terrestre. Fonte: IBGE (2006) adaptado de Heymann (1993).

Figura 5. Ecorregiões do bioma Cerrado. Fonte: Arruda (2008). 11

Figura 6. Localização da área de estudo e dos munícipios do estado de Goiás. 13

Figura 7. Classes de uso e cobertura da terra da área de estudo no ano de 2011. Fonte: MACROZAEE-GO (2014). 15

Figura 8. Geologia da área de estudo. Fonte: EIBH (2005). .17

Figura 9. Mosaico das cenas SRTM (A); composição colorida R/G/B (Curvatura Máxima/Declividade/Curvatura Mínima) (B). 22

Figura 10. Mapa das unidades de relevo da área de estudo. .24

Figura 11. Transecto do perfil topográfico A-B-C nas unidades de relevo (a) e nas formações geológicas (b) da área de estudo. .25

Figura 12. Perfil topográfico das unidades de relevo relacionadas com formações geológicas da área de estudo.

Figura 13. Histogramas de frequência de altimetria e declividade das unidades de relevo. .26

Figura 14. Gráfico representando a distribuição da área (\%) das unidades geológicas em cada unidade de relevo. .27

Figura 15. Assinatura de uso e cobertura da terra nas unidades de relevo. .29

Figura 16. Gráfico representando a distribuição de área (\%) das classes de uso e cobertura da terra em cada unidade de relevo. .30

Figura 17. Histogramas de frequência de altimetria e declividade das classes de uso e cobertura da terra. .31 


\section{LISTA DE TABELAS}

Tabela 1. Chave para identificação de unidades geomorfológicas em composição colorida R/G/B (Curvatura M/Declividade/Curvatura Mínima). Fonte: Adaptado Sena-Souza (2013). 


\section{RESUMO}

\section{RELAÇÕES ENTRE O RELEVO E A ORGANIZAÇÃO ESPACIAL DO USO E COBERTURA DO SOLO NO SUDOESTE DO ESTADO DE GOIÁS}

O relevo é um dos fatores que formam a paisagem, fundamental para análise da cobertura da terra e o planejamento ambiental. Dentro deste contexto se insere o presente trabalho, cujo objetivo foi estudar as relações entre os padrões de relevo e a organização do uso e cobertura do solo das bacias hidrográficas do Rio Paranaíba, Rio do Peixe, Rio Bonito, Rio Diamantino, Rio dos Bois e Rio Claro, localizadas no sudoeste do estado de Goiás, e representativas dos sistemas agrícolas da ecorregião Paraná-Guimarães. O mapeamento das unidades de relevo consistiu na utilização de cenas da missão Shuttle Radar Topography Mission (SRTM) e posteriormente a classificação supervisionada para delimitação dos compartimentos de relevo. Para integração das informações obtidas do relevo com os dados geológicos e de uso e cobertura da terra, foram utilizadas a base do acervo de Estudos Integrados de Bacias Hidrográficas (EIBH), Sudoeste do Estado de Goiás e do Macrozoneamento Agroecológico e Econômico do estado de Goiás (MACROZAEE-GO), respectivamente. Foi possível identificar oito unidades de relevo dentro da área de estudo: Planalto Residual (15,53\%), Planalto Parcialmente Denudado (6,20\%), Mesa (1,43\%), Frente de Recuo Erosivo (7,60\%), Rampas de Colúvio (7,45\%), Depressão Intraplanáltica (22,80\%), Depressão Dissecada (35,35\%) e Planície Fluvial $(3,64 \%)$. De modo geral, em todas as unidades de relevo se verificou a relação existente com as unidades geológicas e com as classes de uso e cobertura da terra. A Depressão Dissecada sobre a Formação Adamantina dominam as coberturas formadas por pastagens cultivadas e constitui a unidade mais representativa em termos de área e delimitação da paisagem. Por outro lado, no Planalto Residual e no Planalto Parcialmente Denudado sobre a Formação Cachoeirinha predominam a cobertura agrícola. $\mathrm{O}$ estudo mostrou que a ação antrópica predomina sobre relevos planos e contínuos e também em áreas de relevo ondulado e de baixas altitudes. Nas áreas com declividade elevada a cobertura de cerrado se destaca em função das limitações de outros tipos de uso. Conclui-se que a abordagem utilizada de mapeamento do relevo constitui uma importante ferramenta nos estudos de paisagem.

Palavras-chave: geomorfologia, organização espacial do uso e cobertura da terra, paisagem. 


\section{ABSTRACT \\ RELATIONS BETWEEN RELIEF AND SPATIAL ORGANIZATION OF THE USE AND LAND COVER IN SOUTHWESTERN GOIÁS}

The relief is one of the factors of landscape, fundamental for the analysis of land cover and environmental planning. This study presents the relationship between the relief patterns and land use land cover organization on watersheds Paranaíba River, Peixe of River, Bonito River, Diamantino River, Bois of River, located in Southwest Goiás and, representative of farming systems the Paraná-Guimarães ecoregion. The mapping of landscape units was the use scenes of Shuttle Radar Topography Mission (SRTM) and later the supervised classification for delimitation of the relevant compartments. For integration of information obtained relief with geological data and use and land cover were used to base the Integrated Watershed Studies (EIBH), Southwestern Goiás and the Agroecological and Economic Macrozoning of state Goiás (MACROZAEE-GO), respectively. Was identified eight relevant units within the study area: Residual Plateau (15.53\%), Partly Denudated Plateau (6.20\%), Mesa (1.43\%), Erosive Front (7.60\%), Colluvial Ramps (7.45\%), Intraplanaltic Depression (22.80\%), Dissected Depression $(35.35 \%)$ and Plain River (3.64\%). In general, in all relevant relief units was found the relationship with the geological units and the land use and land cover classes. In the Dissected Depression on Adamantina Formation dominate the cultivated pastures is the most representative unit in terms of area and delimitation of the landscape. On the other hand, the Residual Plateau and Partly Denudated Plateau on Cachoeirinha Formation and Cobertura Arenosa predominates agricultural cover. The study showed that human action predominates over plans and continuous relief and also in areas of undulating relief and low elevations. In areas with high slope the cerrado cover stands out due to the limitations of other types of use. The study concludes that the relief mapping approach used is an important tool in landscape studies.

Key words: geomorphology, spatial organization of land use and land cover, landscape 


\section{ORGANIZAÇÃO DA DISSERTAÇÃO}

Este trabalho foi estruturado em formato de artigo científico, no intuito de ampliar a disseminação do conhecimento acerca das relações das formas de relevo e a distribuição espacial do uso e cobertura da terra.

O capítulo 1 contextualiza a temática trabalhada na dissertação, com a apresentação geral acerca dos assuntos abordados e os objetivos gerais e específicos do presente trabalho.

O capítulo 2 corresponde ao artigo intitulado "Relações entre o relevo e a organização espacial do uso e cobertura do solo no sudoeste do estado de Goiás". Neste trabalho relacionou-se o mapeamento das unidades de relevo com as informações de uso e cobertura do solo do Sudoeste Goiano na ecorregião do Paraná-Guimarães. Este trabalho evidenciou padrões das unidades de relevo e a integração na paisagem com as classes de uso e cobertura da terra, sendo estas informações de análise conjunta da paisagem, estratégicas para a gestão dos recursos naturais.

As considerações finais deste trabalho são apresentadas no capítulo 3, no qual foram apontadas as principais perspectivas obtidas com base nos resultados detectados. Dentre as quais se destacam a utilização do mapeamento das unidades de relevo em conjunto com as informações de uso e cobertura da terra para ações de planejamento territorial e gestão dos recursos naturais. 


\section{CAPÍTULO 1 - APRESENTAÇÃO GERAL}

\subsection{INTRODUÇÃO}

O relevo constitui a unidade básica dos aspectos geomorfológicos na organização espacial e temporal da terra, cujas unidades de relevo são delimitadas a partir de características geológicas, pedológicas e climáticas que, em conjunto com os componentes bióticos e antrópicos, possibilitam uma visão integrada da paisagem (Ab'Sáber 1977).

O modo de utilização das propriedades de suporte e recurso do relevo contribuem para a formação das diferentes unidades de paisagem (Ab'Sáber 1975, Martins et al. 2004, Casseti 2005), sendo o relevo um importante aspecto para a compreensão da distribuição espacial da cobertura da terra (Couto Jr. 2007).

Apresentando pronunciada heterogeneidade de paisagens (Ratter et al. 1997, Silva et al. 2006), o Cerrado se destaca por apresentar ocupação do solo condicionada por características ambientais regionais como as formas de relevo. O Cerrado apresenta relevo em planaltos cristalinos ou blocos sedimentares contínuos (Brasil \& Alvarenga 1989), que possibilita a implantação da agricultura e pecuária no bioma, devido essas formas de terreno favorecerem a aplicação de técnicas de correção dos solos altamente intemperizados e ácidos (Ratter et al. 1997).

Em função da similaridade dos fatores estruturais e dinâmicos da paisagem do Cerrado foram identificadas 22 (vinte e duas) ecorregiões considerando a distribuição espacial desses elementos (Arruda et al. 2008). Dentre essas unidades de paisagem, a ecorregião do Paraná-Guimarães destaca-se com relevante área de agropecuária, cuja ocupação foi condicionada, principalmente, pela distribuição dos padrões de relevo.

Inserida na ecorregião Paraná-Guimarães, o sudoeste do estado de Goiás apresenta paisagem predominante agropecuária, com diferentes cultivos agrícolas e grandes extensões de pecuária (Guerra et al. 1989). Tendo sido a pecuária, a principal responsável pela transformação das paisagens naturais, dessa região, acompanhada da agricultura que apresentou ocupação mais recente neste processo (Oliveira 2005), devido as políticas governamentais de incentivos fiscais federais a partir de 1970 (Alho \& Martins 1995). 


\subsection{OBJETIVOS}

\subsubsection{Objetivo Geral}

Apresentar as relações entre os padrões de relevo e a organização espacial do uso e cobertura do solo das bacias hidrográficas do Rio Paranaíba, Rio do Peixe, Rio Bonito, Rio Diamantino, Rio dos Bois e Rio Claro, localizadas no Sudoeste Goiano, representativas dos sistemas agrícolas da ecorregião Paraná-Guimarães.

\subsubsection{Objetivos Específicos}

a) Mapear as unidades de relevo das bacias hidrográficas do Rio Paranaíba, Rio do Peixe, Rio Bonito, Rio Diamantino, Rio dos Bois e Rio Claro.

b) Descrever as unidades de relevo encontradas na área de estudo e as relações com a organização espacial do uso e cobertura do solo da região.

\subsection{FORMAÇÃO DO RELEVO}

Objeto de estudo da geomorfologia, o relevo consiste em um conjunto de modelado da superfície terrestre, isto é, representa as elevações e formas da terra. Para a avaliação da evolução dessas formas de terreno é necessária a observação dos processos endógenos e exógenos que podem constituir-se em fatores de potencialidades de atividades de uso da terra (Ab'saber 1969, Casseti 2005).

No Brasil, a ação dos processos endógenos e exógenos atuantes nas formações geológicas do território brasileiro possibilitou o desenvolvimento de grande variedade de formas do relevo, como os planaltos, chapadas, tabuleiros, serras e patamares, que atingem altitudes elevadas e também as áreas de menores altitudes, como as planícies e depressões (IBGE 2009).

Os processos endógenos estão relacionados a movimentos no interior da Terra (tectonismo, vulcanismo e abalos sísmicos), e são responsáveis pela diferenciação nas formas do relevo. Os principais movimentos internos da Terra que participam na formação e transformação do relevo, sob o aspecto do tempo geológico, são a orogênese, a epirogênese e a subsidência (Press et al. 2006).

A orogênese ocorre em movimentos tectônicos horizontais, que podem ser o choque entre duas placas tectônicas denominados de convergentes e o asfastamento de duas placas tectônicas, que são os movimentos divergentes (Teixeira et al. 2009). Geralmente, o 
processo de epirogênese acontece em terrenos de abrangência continental, e em áreas de relevo plano e de formação geológica antiga, como é o caso do processo predominante na Plataforma Sulamericana. Esse movimento é um dos agentes causadores da transgressão marinha, em que ocorre o avanço do mar nas áreas continentais, e a regressão marinha, que é o recuo das águas oceânicas (Wicander \& Monroe 2009).

Enquanto que os processos endógenos atuam principalmente na formação do relevo, os processos exógenos, com movimentos no exterior da crosta terrestre e ações provenientes tanto de fenômenos naturais da superfície da terra (ações pluviometricas, marítimas, glaciais, fluviométricas, biológicas e intempéricas), quanto como de atividades antrópicas são os responsáveis pelo modelado da superfície terrestre (Porto 2009).

O intemperismo é de grande relevância no processo exógeno e, por sua vez, nas formas do terreno. O intemperismo consiste nas modificações de ordem física e química das rochas que afloram na superfície da terra (Teixeira et al. 2009) e por isso é um importante processo de transformação do relevo ao longo do tempo.

Os processos que causam a desagregação das rochas, separando grãos de minerais ordenados de modo coeso e transformando-os em material descontínuo e friável constitui no intemperismo físico, em que a água, umidade e a temperatura são os principais agentes responsáveis pelas modificações de ordem física das rochas, e consequentemente do modelado da superfície terrestre (Suguio 2000).

O intemperismo físico tem maior representação nos ambientes áridos, onde o intemperismo químico é menos intenso. No entanto, o intemperismo químico auxilia no intemperismo físico ao favorecer a desagração das rochas por meio da biota, como raízes e bactérias que penetram em fendas e causam reações químicas (Press et al. 2006).

A fragmentação das rochas no intemperismo físico pode ocorrer pelas foliações em rochas metamórficas, estratificação das rochas sedimentares nas zonas de fraqueza e pelas fraturas geradas pelo alívio da pressão. O ciclo de gelo nas áreas frias possibilita as fraturas pelo congelamento das águas em fendas, que se expandem e originam novas fraturas. As variações de temperatura com aquecimento e resfriamento das rochas geram mudança de volume, no qual ocorrem as deformações elásticas. A partir da ação dos agentes intempéricos (umidade, alívio e pressão, ciclos gelo e degelo e variação de temperatura), as rochas são desintegradas, resultando em sedimentos de tamanhos variados sem alteração da composição mineralógica (Teixeira et al. 2009).

As modificações químicas da rocha que originam o intemperismo químico ocorrem 
quando acontece a decomposição da estrutura química dos minerais que a compõe, sendo por meio da reação com os agentes intempéricos ar e a água, sendo formados novos minerais nos ambientes da superfície terrestre (Albarede 2011).

Dentre os agentes intempéricos, a água se destaca pela abrangente atuação nos processos de intemperismo químico de hidrólise, hidratação e desidratação, carbonatação e oxidação que ocorrem por meio das águas das chuvas, rios, mares e oceanos, e favorecem o desenvolvimento de rupturas no relevo, auxiliando na modelagem da superfície terrestre e nas formações geológicas (Hypolito et al. 2011).

O processo de hidrólise trata-se da reação mais comum para a quebra das ligações dos minerais silicatados pela ação dos íons $\mathrm{H}^{+} \mathrm{e} \mathrm{OH}^{-}$da água. Os minerais reagem com os íons $\mathrm{H}^{+}$liberados pela água, e os agrega a composição mineralógica e colocam em solução o $\mathrm{OH}^{-}$e os íons originais dos silicatados, causando um desequilíbrio na estrutura cristalina do mineral, que possibilita a geração de minerais secundários (Rohde 2013). Este é o processo mais importante de desenvolvimento de solos em condições tropicais.

A hidratação e a desidratação são a entrada e saída das moléculas de água na estrutura dos minerais. A adição e adsorção de água na estrutura do mineral causa a hidratação de alguns minerais por meio da transformação física e química causando expansão e fratura na rocha. $\mathrm{Na}$ desidratação, os minerais sofrem perda de água, que resulta na redução de volume (Rohde 2013).

O processo de carbonatação acontece pela dissolução do gás carbônico na água, que resulta no ácido carbônico. A carbonatação se concentra nas rochas calcárias, que possuem solubilidade maior em água com gás carbônico do que em água pura (Hypolito et al. 2011).

A oxidação é a formação de óxidos ou hidróxidos formados pela reação do oxigênio com o ferro. A combinação do oxigênio com a estrutura cristalina do ferro e outros minerais, quando ocorre através da água, gera compostos minerais secundários. $\mathrm{O}$ intemperismo químico é mais comum em climas úmidos, em que as reações químicas geralmente resultam em novas composições mineralógicas (Porto 2009).

Os cursos d'água estão diretamente relacionados com os processos de erosão, transporte e deposição de sedimentos produzidos pelo intemperismo. A erosão é causada pelo transporte de material alterado para serem depositados em outro local, sendo esse material movido e favorecendo o afloramento de novas rochas. O intemperismo e a erosão são processos que agem em conjunto na formação de rochas sedimentares e na dinâmica de transformação do relevo (Passos \& Bigarella 2009). 


\subsection{MAPEAMENTO DAS UNIDADES DE RELEVO}

Dentre as diferentes técnicas para confecção dos mapas de relevo, o método de composição colorida se destaca pela possibilidade de distinção das unidades de relevo por meio da análise visual, considerando a variação de cor, forma e textura nas imagens.

Esse método associa as variáveis morfométricas às três cores primárias: vermelho $(\mathrm{R})$, verde (G) e azul (B). Essa combinação de cores RGB consiste na disposição das informações contidas nas imagens em cada canal de cor, visando o melhor realce dos dados (Meneses et al. 2012).

A partir da composição colorida das variáveis morfométricas em RGB, os padrões de cor, textura e forma são vetorizados por meio de digititalização manual e, depedendo da extensão das áreas estudadas, por métodos de classificação supervisionada e não supervisionada.

A aplicação dessa metodologia, utilizando unidades morfométricas, foi realizada por Hermuche et al. (2002), no intuito de subsidiar o mapeamento pedológico em bacias hidrográficas assimétricas. Os autores utilizaram duas composições coloridas para melhor extração das informações: a) altimetria/declividade/área de contribuição; b) altimetria/declividade/aspecto nos canais de cor RGB, respectivamente. Observou-se que o emprego da composição colorida para realçar os padrões morfométricos auxiliou na compreensão da relação dos tipos de solos com as características de relevo da área de estudo.

Um dos exemplos da aplicação desta metodologia no mapeamento geomorfológico da bacia hidrográfica do São Bartolomeu, localizada no Distrito Federal e Goiás, foi feita por Sena-Souza et al. (2013) na escala de 1:100.000. Os canais R e G foram utilizados para o preenchimento dos dados de altitude e declividade e no canal B depende do objetivo do trabalho e das características da área de estudo.

Sena-Souza et al. (2013) utilizaram a composição que melhor evidenciou as unidades de relevo da área, sendo a altimetria (R), declividade (G) e curvatura mínima (B). As unidades geomorfológicas foram identificadas por meio da interpretação visual da composição colorida RGB e posteriormente realizada a vetorização digital em tela para geração dos polígonos das unidades de relevo (Figura 1). Conforme o procedimento adotado, foram encontradas as seguintes unidades geomorfológicas (Figura 2): chapadas, frentes de recuo erosivo, rampas de colúvio, depressões dissecadas, mesas, cristas, colinas e planícies fluviais. De acordo com os autores, a identificação das unidades de relevo por 
meio da composição colorida permitiu observar a relação entre os aspectos pedológicos, geológicos e geomorfológicos.

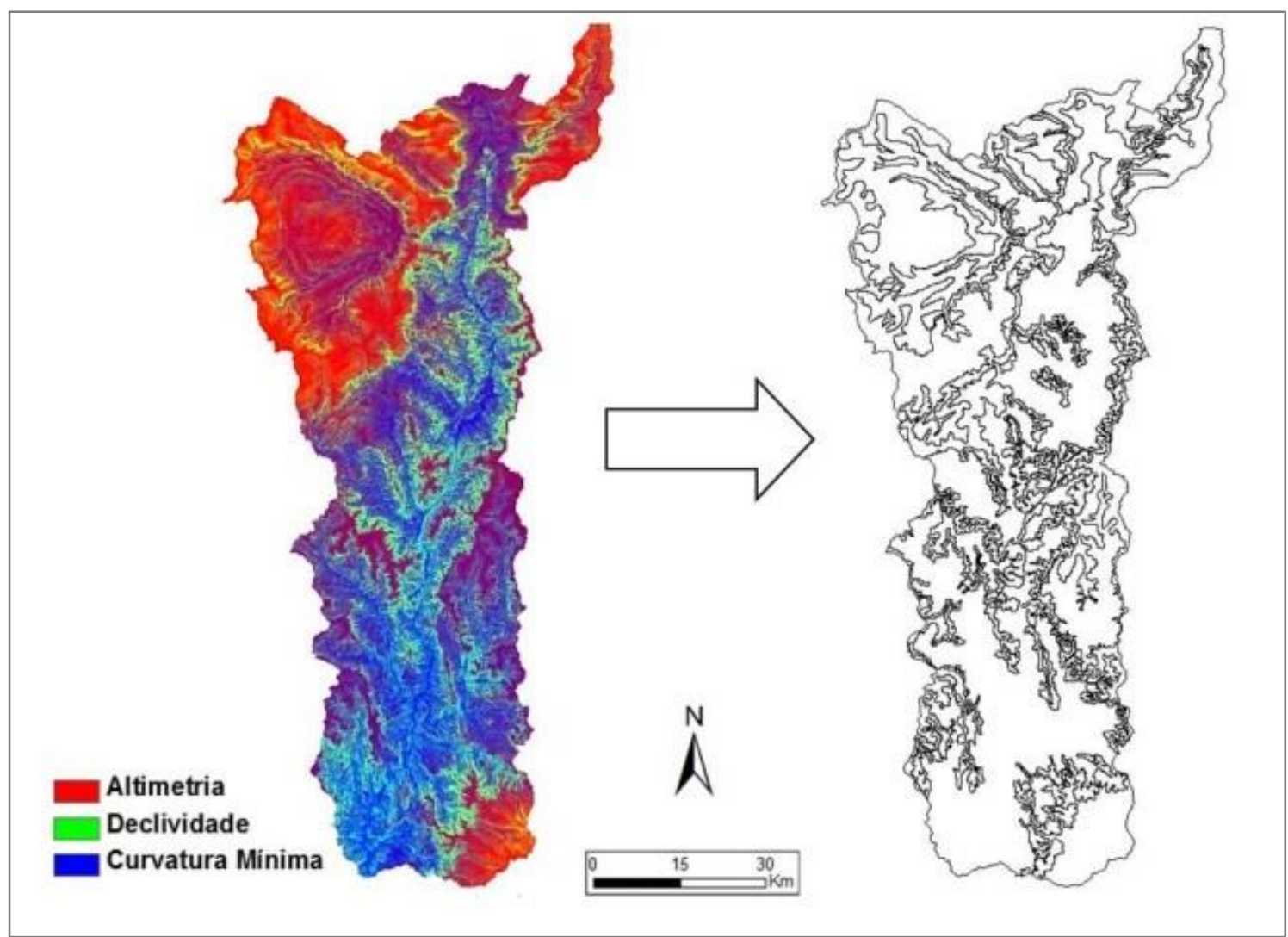

Figura 1. Composição Colorida RGB (à esquerda) e vetores (polígonos) gerados com base nos padrões de cores da imagem. Fonte: Sena-Souza et al. (2013).

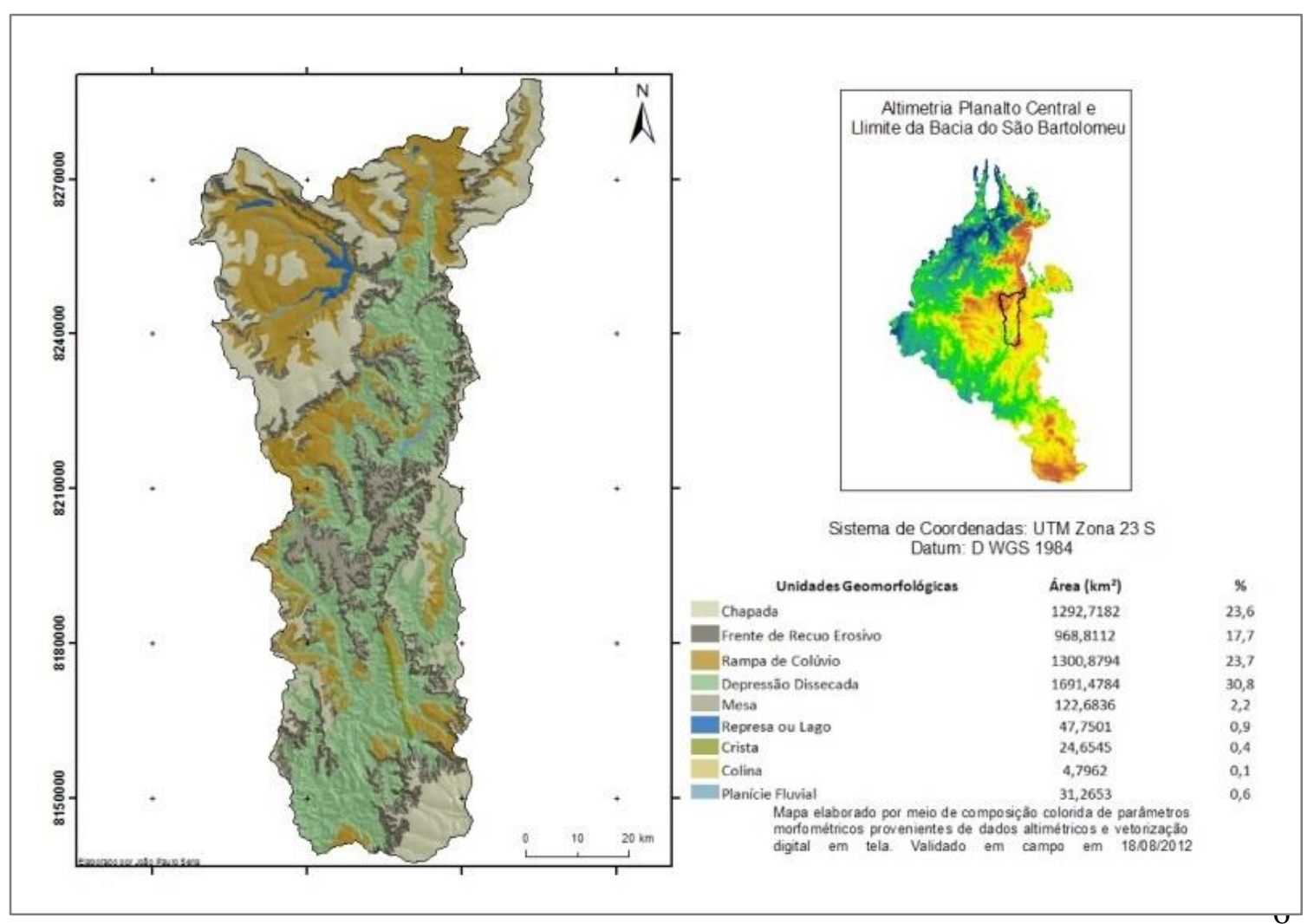

Figura 2. Resultado do mapeamento das unidades geomorfológicas usando a composição colorida para realce das feições das variáveis morfométricas. Fonte: Sena-Souza et al. (2013). 
Ao realizar o mapeamento geomorfológico aplicado ao estudo de uso e ocupação da terra, Mendes (2015) utilizou as composições coloridas altimetria (R), declividade (G) e curvatura mínima (B), que apresentou melhor contraste na discriminação das unidades geomorfológicas, sendo essa disposição RGB encontrada nos trabalhos de Lima et al. (2010a), Castro et al. (2010a) e Sena-Souza et al. (2013). A autora observou que as unidades geomorfológicas são representações de compartimentos do relevo capazes de explicar a organização do espaço e a distribuição de uso e cobertura da terra, apresentando os seguintes resultados: nas chapadas e remanescentes o uso potencial são para as classes de agricultura e cerrado, nas rampas de colúvio I e II, planalto retocado e depressão dissecada se destacam o uso em agricultura, pastagem e cerrado e nas unidades de frente de recuo erosivo e serras são encontrados uso para floresta e cerrado.

A partir do mapeamento das unidades de relevo se verifica a necessidade da realização da taxonomia dessas unidades. Os táxons definido pelo Instituto Brasileiro de Geografia e Estatistíca-IBGE (2009) abrangem quatro níveis hierárquicos (Figura 3) que são individualizados de acordo com fatores causais, de natureza estrutural, litológica, pedológica, climática e morfodinâmica que são responsáveis pela evolução das formas do relevo e pela composição da paisagem no decorrer do tempo geológico.

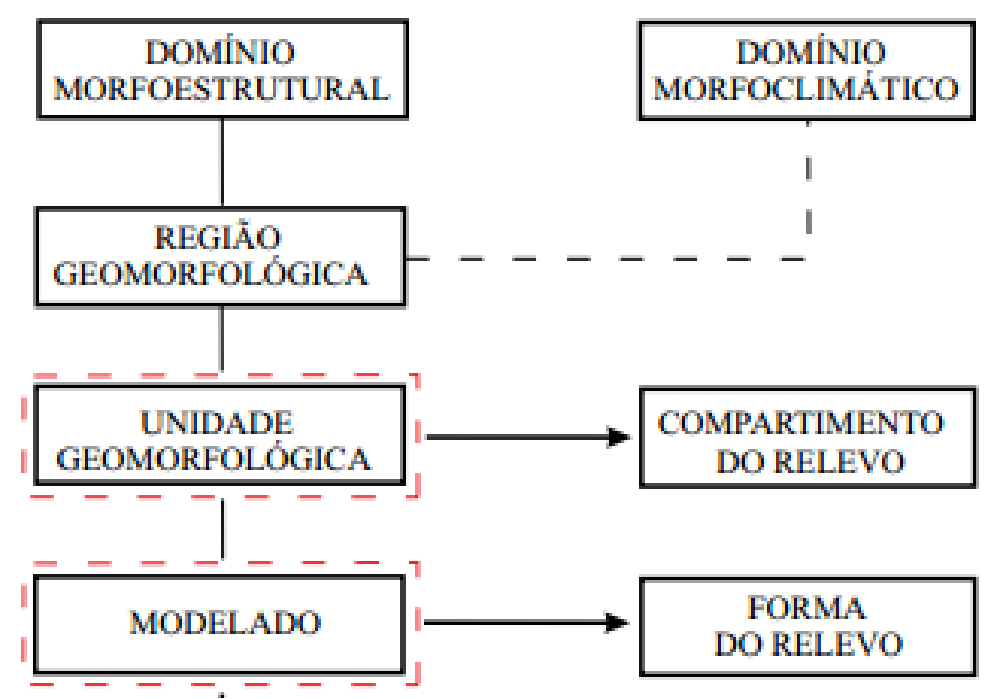

Figura 3. Nomenclatura das unidades de relevo. Fonte: Adaptado IBGE (2009).

Os Domínios Morfoestruturais são táxons que representam os maiores compartimentos de relevo servindo de suporte para as morfoesculturas que se configuram no resultado das ações climáticas sobre a estrutura litológica (Ross 1992). Os Domínios Morfoestruturais ocorrem em escala regional e são fortemente associados a estrutura geológica de origem, 
devido a organização dos aspectos geomorfológicos nesse nível hierárquico ocorrer de acordo com a natureza das rochas e a tectônica atuantes sobre elas (IBGE 2009).

As Regiões Geomorfológicas estão inseridas nas feições litomorfoestruturais que são originadas a partir das ações climáticas passadas e atuais. A compartimentação das Regiões Geomorfológicas é realizada por meio da associação de feições semelhantes de formações superficiais e de fitofionomias, além da distribuição espacial e a localização geográfica como fatores de individualização desse táxon (IBGE 2009).

As Unidades Geomorfológicas são definidas pela similaridade das formas altimétricas e pelas fisionomias das unidades de relevo (IBGE 2009). Os canais de drenagens são fatores de grande influência nos processos originários, formações superficiais e os diferentes tipos de modelados das unidades de relevo, em razão de evidenciar as relações existentes entre os ambientes climáticos atuais e passados e as condições litológicas e tectônicas (IBGE 2009). As fomas de relevo que compõem essas unidades são as planícies, depressões, tabuleiros, chapadas, patamares, planaltos e serras. Essas Unidades Geomorfológicas são os táxons de interesse neste estudo devido a facilidade na distinção das diferentes características de altitudes e fisionomias do relevo por meio da rugosidade topográfica e da intensidade de dissecação (Ross 1992).

Os Modelados são formas de relevo geometricamente similares em virtude de uma gênese comum e processos morfogenéticos atuantes (IBGE 2009). De acordo com a metodologia adotada pelo IBGE são definidos quatro tipos de modelados: acumulação, aplanamento, dissolução e dissecação.

\subsection{MAPEAMENTO DO USO E COBERTURA DA TERRA}

A maneira pela qual os atributos biofísicos da superfície terrestre são modificados (cobertura da terra) está relacionada basicamente aos objetivos de natureza humana (uso da terra), cujas consequências são de grande relevância para as mudanças ambientais globais (Lambin et al. 1999). Essas modificações, quando ocorrem com ausência de planejamento ambiental, acarretam grandes impactos ambientais como a redução da disponibilidade de recursos hídricos, alterações dos ciclos biogeoquímicos e nas baixas concentrações de nutrientes do solo, que tem como um dos fatores desencadeadores a ausência de cobertura vegetal original da terra (Austin et al. 2013).

Os mapas de cobertura da terra são importantes ferramentas para o planejamento ambiental, cuja função é fornecer informações acerca do território, em escala de 
abrangência local e regional, com possibilidade de relacionar diferentes escalas (IBGE 2006).

O mapeamento do uso e cobertura da terra consiste na observação da escala e definição da unidade de mapeamento, no tamanho da menor unidade de área mapeável e na definição da nomenclatura das classes mapeadas (Heymann et al. 1993).

A escala de mapeamento está relacionada com a análise da distância do ambiente real com a determinação da distância do material cartográfico (IBGE 1985). De acordo com o Manual Técnico de Uso da Terra (IBGE 2006) a unidade de mapeamento consiste nas classes de uso e cobertura da terra que se expressam em maior ou menor grau de forma homogênea na superfície terrestre. O tamanho da menor unidade de área mapeada é $5 \mathrm{~mm}$ x $5 \mathrm{~mm}$ na representação cartográfica, sendo definido a partir do objetivo do trabalho, se requer maior ou menor detalhe de informações da área de estudo. A nomenclatura tem o objetivo de separar as classes de uso e cobertura da terra em níveis hierárquicos de acordo com as especificidades e características de cada classe (Figura 4).

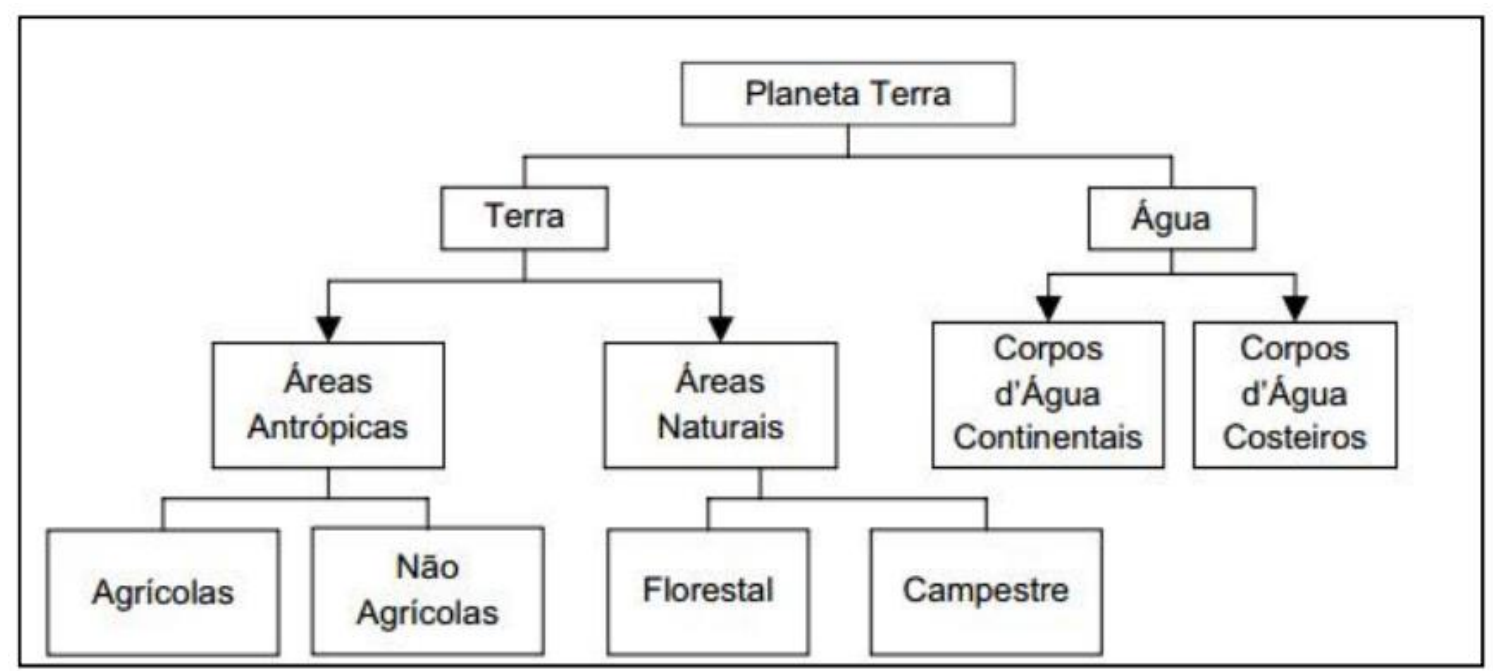

Figura 4. Esquema teórico de construção de uma nomenclatura da cobertura terrestre. Fonte: IBGE (2006) adaptado de Heymann (1993).

Essas informações auxiliam no manejo eficiente dos recursos naturais, agrícolas e hídricos, espacializando as formas de ocupação e a proporção de áreas de cobertura da terra, possibilitando a realização do planejamento ambiental dos territórios. 


\subsection{ECORREGIÕES DO CERRADO}

O bioma Cerrado é caracterizado por formações florestais (Mata Ciliar, Mata de Galeria, Mata Seca e Cerradão), savânicas (Cerrado sentido restrito, Parque de Cerrado, Palmeiral e Vereda) e campestres (Campo Sujo, Campo Limpo e Campo Rupestre) e por possuir a maior biodiversidade e heterogeneidade de paisagens dentre as savanas do mundo (Silva \& Bates 2002, Silva et al. 2006, Ribeiro \& Walter 2008).

As classes de cobertura antrópica do Cerrado possuem grandes porções de terra que se concentram em maior parte na região sul do bioma, com predomínio de pastagens cultivadas e culturas agrícolas (Sano et al. 2008). As áreas naturais do Cerrado representam 60, 5\% de fisionomias savânicas, 32\% de fisionomias florestais e $7 \%$ de fisionomia campestre (Sano et al. 2009). As características ambientais regionais como relevo, geologia e clima contribuem para a conservação dessas áreas, além de serem um importante aspecto para a compreensão da distribuição espacial da cobertura da terra no bioma.

Empregadas como referência para o planejamento ambiental regional do bioma Cerrado foram identificadas 22 (vinte e duas) ecorregiões (Arruda et al. 2008), de acordo com aspectos biogeográficos (Figura 5): Alto Parnaíba, Araguaia Tocantins, Bananal, Bico do Papagaio, Chapadão do São Francisco, Chiquitania, Complexo Bodoquena, Depressão Cuiabana, Depressão do Parnaguá, Grão-Mogol, Jequitinhonha, Paracatu, ParanáGuimarães, Paranaíba, Paranapanema Grande, Parecis, Planalto Central Goiano, Província Serrana, São Francisco-Velhas, Serra da Canastra, Serra do Cipó e Vão do Paranã.

As ecorregiões são definidas como um conjunto de comunidades naturais, distintas geograficamente, que apresentam características ecossistêmicas similares (Dinerstein et al. 1995). Por possuir limites naturais bem definidos, a abordagem por ecorregiões auxilia na representatividade ecológica dos ecossistemas e no manejo de ecossistemas com maior sustentabilidade e conservação da biodiversidade (Miller 1997). As ecorregiões evidenciam a distribuição espacial da biodiversidade (Bailey 2005, Ximenes et al. 2009) e por isso são muito úteis para a definição de estratégias eficientes de planejamento ambiental.

Dentre as ecorregiões do bioma Cerrado, destaca-se a ecorregião Paraná-Guimarães, possuindo a maior extensão territorial do bioma com $377.902 \mathrm{~km}^{2}$, que corresponde a 18,87\% do território do Cerrado, abrangendo os estados de São Paulo, Minas Gerais, Mato Grosso do Sul e Goiás. Inserida na porção sudoeste do bioma, apresenta características 
ambientais de ampla extensão de áreas planálticas, grande sucessão de formações geológicas e variabilidade de solos que favoreceram a concentração de atividades agrícolas e pecuária.

A ecorregião do Paraná-Guimarães apresenta variedade geomorfológica que abrange degraus dispostos em patamares a formas mistas de aplainamento e dissecação fluvial com presença de mesas. Possui altitudes que variam de 300 a 1000 metros. Inserida no sistema hidrográfico da Bacia do rio Prata, possui dentre suas principais sub-bacias o rio Paraguai e o rio Paraná. A geologia corresponde às camadas sedimentares e aos derrames basálticos da Bacia do Paraná. São encontrados os Latossolos em maior parte das áreas da ecorregião.

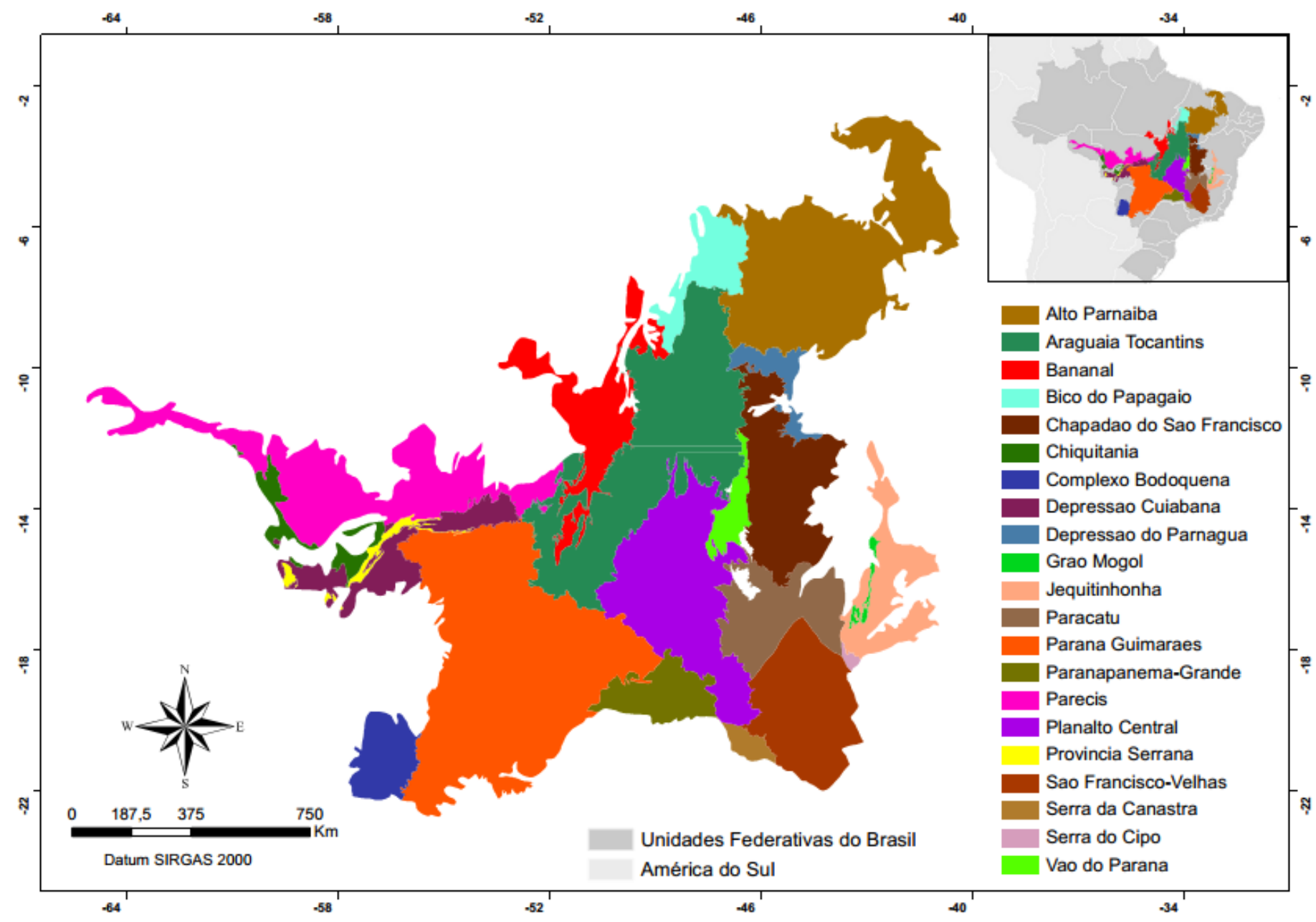

Figura 5. Ecorregiões do bioma Cerrado. Fonte: Arruda (2008). 


\section{CAPÍTULO 2 - RELAÇÕES ENTRE O RELEVO E A ORGANIZAÇÃO ESPACIAL DO USO E COBERTURA DO SOLO NO SUDOESTE DO ESTADO DE GOIÁS}

\subsection{INTRODUÇÃO}

O relevo é um dos fatores condicionantes para a delimitação da paisagem, fundamental para análise da cobertura da terra (Ab'Saber 1950), e de estratégias de planejamento ambiental (Casseti 2005).

As unidades de relevo são determinantes para as categorias de uso da terra, visto que os padrões de ocupação da cobertura da terra ocorrem de maneira diferenciada de acordo com os tipos de relevo, demonstrando a relevância do mapeamento geomorfológico em conjunto como o mapeamento de uso e cobertura da terra como componentes indispensáveis no planejamento territorial (Christofoletti 1994, Baran-Zgłobicka \& Zgłobicki, 2012).

A obtenção de informações acerca da cobertura da terra se insere na gestão dos recursos naturais e no monitoramento ambiental, sendo de grande relevância na análise dos processos e problemas ambientais associados à gestão do espaço territorial (Anderson et al. 1976, Oliveira 1988, Copeland et al. 1996, Rawat et al. 2013).

Dentre os produtos disponíveis para aprimoramento das informações espaciais da cobertura da terra estão os dados de sensoriamento remoto, que possibilitam utilização na gestão do espaço geográfico (IBGE 2006). Os dados de sensoriamento remoto facilitam a integração com dados de diferentes fontes, proporcionando maior compreensão da distribuição espacial da cobertura da terra e auxiliando no ordenamento do território (Rosa 2005, Araújo Filho et al. 2007).

A distribuição espacial da cobertura da terra pode ser organizada em função das formas de relevo. A agricultura, por exemplo, tende a ocupar áreas planas contínuas, onde o acesso de maquinário é permitido para o manejo. Por outro lado, áreas mais íngremes tendem a permanecer preservadas pela dificuldade no manejo (Ross 2009).

O bioma Cerrado representa essa organização da cobertura da terra em função do relevo, cuja agricultura foi promovida, inicialmente, em áreas planas a partir dos anos de 1970, por meio das políticas públicas visando o desenvolvimento de infraestrutura e logística de transporte para o escoamento da produção e aplicação de pesquisas para obtenção de maior produtividade das áreas. Nas áreas de relevo com maior declividade e acidentados são encontradas a vegetação natural do Cerrado, devido essas áreas favorecerem a conservação de vegetação nativa (Sano et al. 2009). 
Neste contexto, o objetivo deste trabalho foi estudar as relações entre os padrões de relevo e a organização do uso e cobertura do solo das bacias hidrográficas do Rio Paranaíba, Rio do Peixe, Rio Bonito, Rio Diamantino, Rio dos Bois e Rio Claro, localizadas no sudoeste do estado de Goiás, e representativas dos sistemas agrícolas da ecorregião Paraná-Guimarães.

\section{2. ÁREA DE ESTUDO}

A área de estudo abrange uma extensão territorial de $39.170 \mathrm{~km}^{2}$ e está inserida no sudoeste do estado de Goiás, dentro da ecorregião do Paraná-Guimarães (Figura 6). O presente estudo foi realizado nas bacias hidrográficas do Rio Paranaíba, Rio do Peixe, Rio Bonito, Rio Diamantino, Rio dos Bois e Rio Claro. Localizadas na microrregião do Sudoeste Goiano essas bacias apresentam relevância econômica na produção de grãos e no desenvolvimento de importantes agroindústrias da região, abrangendo os municípios de Aparecida do Rio Doce, Aporé, Cachoeira Alta, Caçu, Caiapônia, Chapadão do Céu, Itajá, Itarumã, Jataí, Lagoa Santa, Mineiros, Paranaiguara, Perolândia, Portelândia, Quirinópolis, Rio Verde, São Simão e Serranópolis.

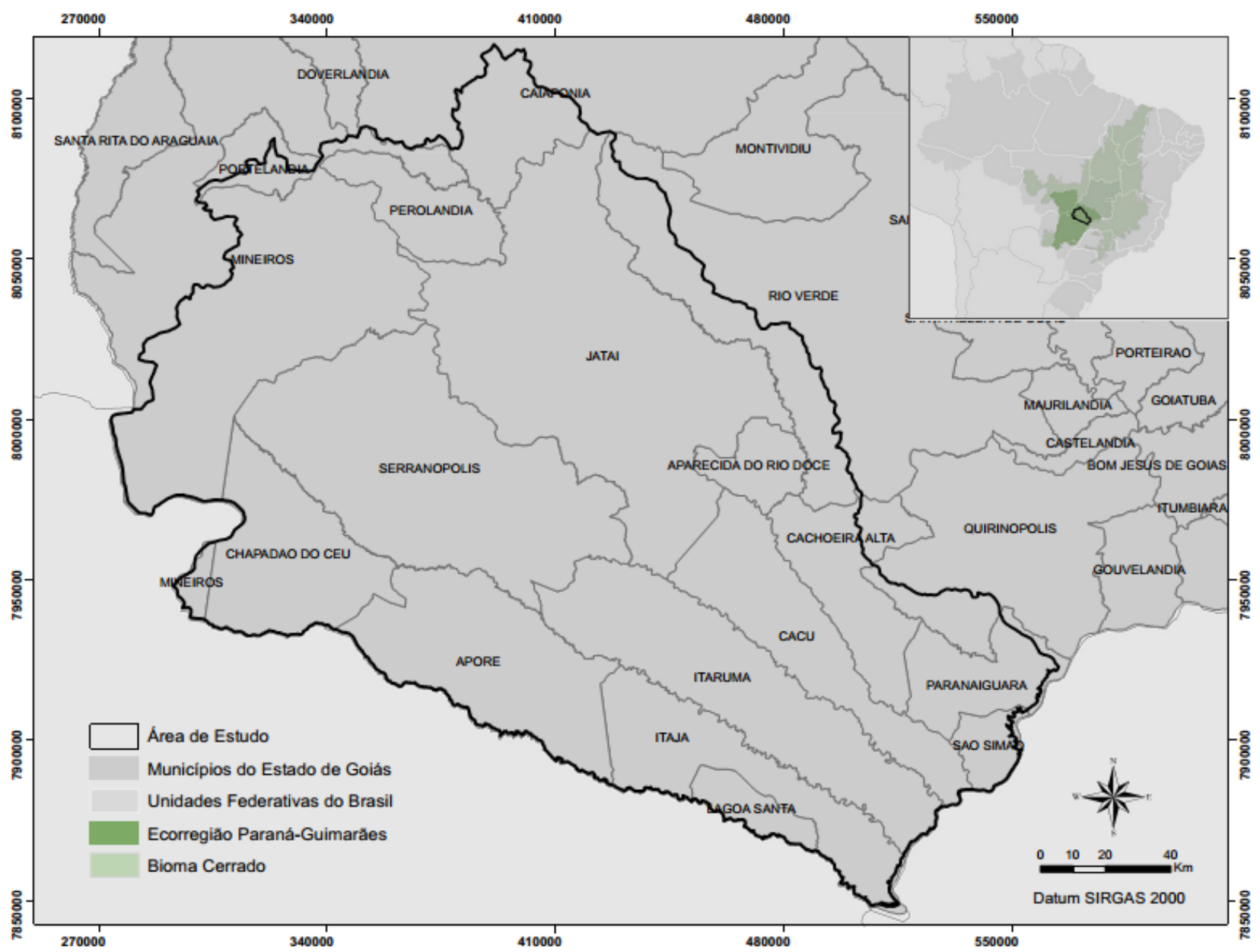

Figura 6. Localização da área de estudo e dos munícipios do estado de Goiás circuvizinhos; sua posição relativa a ecorregião Paraná-Guimarães, ao Bioma Cerrado e as Unidades Federativas do Brasil (direita acima). 
O potencial agrícola da região é evidenciado a partir da distribuição das classes de uso e cobertura da terra (MACROZAEE-GO 2014a) (Figura 7). A obtenção das informações acerca do uso e cobertura da terra da área de estudo foi realizada por meio do acervo digital, disponível em formato vetorial pelo Sistema Estadual de Geoinformação de Goiás (www.sieg.go.gov.br) na escala de 1:250.000, adquiridas em 2014 a partir de dados do Macrozoneamento Agroecológico e Econômico do Estado de Goiás (MACROZAEE-GO) que utilizou imagens do Landsat 5 Thematic Mapper (TM) com resolução de $30 \mathrm{~m}$ do ano de 2011 para o mapeamento do uso e cobertura da terra do estado de Goiás, que incluiu a participação da Secretaria de Estado e Infraestrutura, Cidades e Assuntos Metropolitanos (SICAM), da Secretaria do Meio Ambiente e dos Recursos Hídricos (SEMARH) e da Secretaria da Agricultura e Pecuária (SEAGRO). O intuito do MACROZAEE-GO é subsidiar a elaboração de políticas públicas para o planejamento estratégico de diretrizes de desenvolvimento sustentável de áreas prioritárias do estado de Goiás.

As classes predominantes da cobertura antrópica no Cerrado são as pastagens cultivadas e as culturas agrícolas (Sano et al. 2008). De modo geral, a dinâmica de uso e cobertura da terra do bioma Cerrado reflete no mapeamento de uso da terra de áreas de menor extensão, sendo as bacias hidrográficas da área de estudo um retrato dessa dinâmica.

As áreas de pastagem $(40,87 \%)$ estão concentradas na porção sudeste dessas bacias (Figura 7), e em maior parte sobre relevo suave ondulado, no qual são desenvolvidas as atividades de pecuária de corte, que representam grande importância para a economia regional (Prado et al. 2009). No início do século XVIII, a criação de bovinos no Cerrado era realizada em pastagens naturais apenas para subsistência da população que exercia a atividade de mineração na região (Silva et al. 2013a). A modificação das pastagens naturais para as cultivadas iniciou na primeira década do século XX com o objetivo de atender o crescente mercado de São Paulo e Minas Gerais, por meio de melhorias em infraestruturas de transporte com a abertura de novas estradas nos estados de Goiás e Mato Grosso, e a chegada das ferrovias para maior integração dos estados (Silva et al. 2013b).

A agricultura $(30,90 \%)$ ocupa maiores porções de áreas na parte noroeste e com fragmentos menores distribuídos na porção sudeste. Esse cenário agrícola advém das características geomorfológicas da região, com relevo plano que favoreceram a mecanização e a implantação de políticas públicas realizadas pelo Estado no início dos anos 1970, além das inovações tecnológicas com investimento em pesquisas nas ciências agronômicas, físicas, químicas e biológicas dos solos (Bertran 2000). As áreas urbanas 
$(0,16 \%)$ não possuem representação significativa, sendo a menor classe na região.

A cobertura natural abrange o cerrado $(26,42 \%)$ distribuído ao longo de toda a área de estudo, e com fragmento de maior extensão na parte oeste, onde se localiza o Parque Nacional das Emas, uma das poucas unidades de conservação que apresentam as diversas formas de cerrado dentro do estado de Goiás. A classe de floresta $(0,89 \%)$ possui pequenos fragmentos que ocupam a parte norte da bacia.

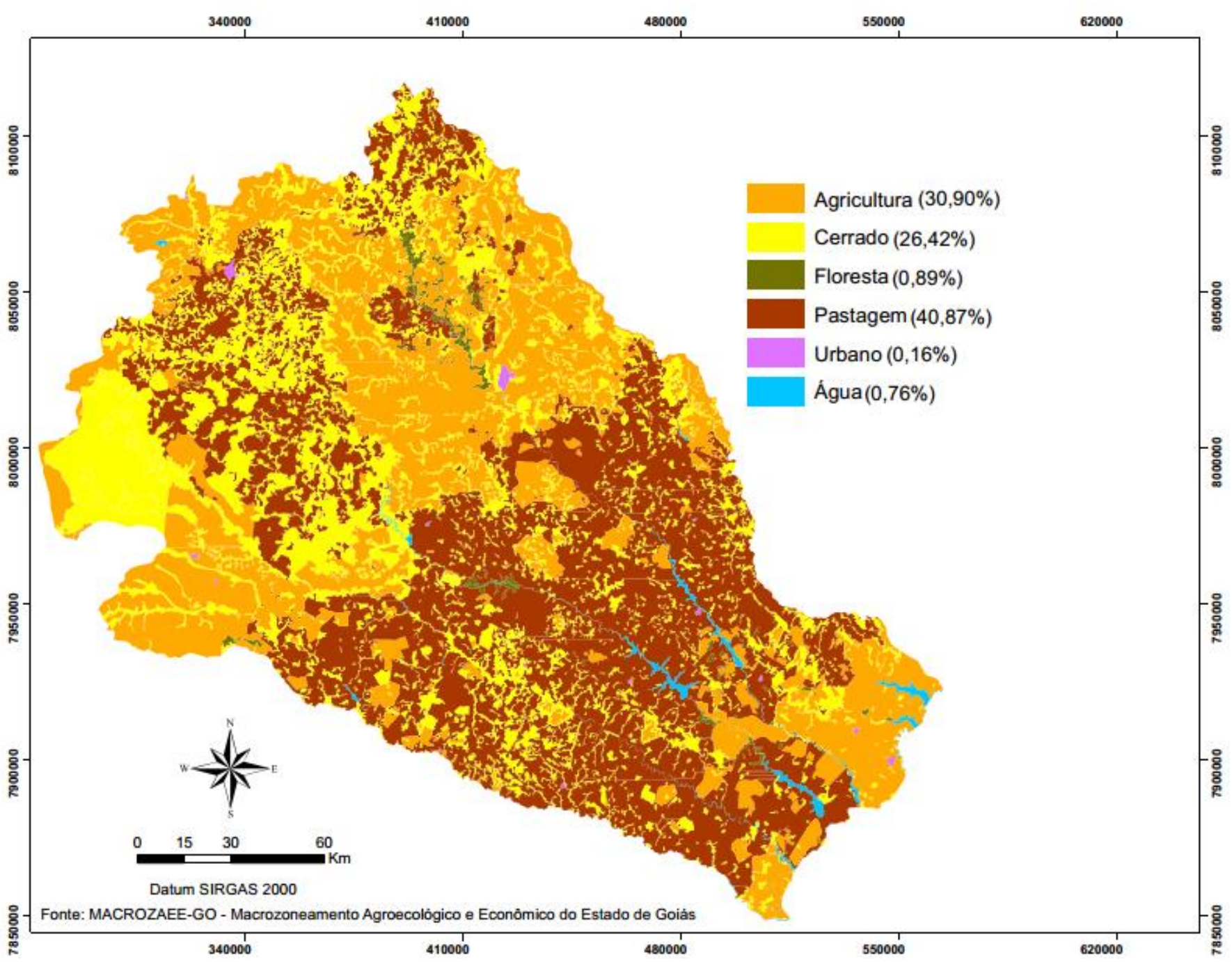

Figura 7. Classes de uso e cobertura da terra da área de estudo no ano de 2011. Fonte: MACROZAEE-GO (2014).

O clima predominante é o Tropical Semi-Úmido Aw (Köppen), sendo observadas duas estações bem definidas: um verão quente e úmido, com chuvas concentradas entre novembro e janeiro, e um inverno mais frio e seco, com estiagem entre julho e agosto. A precipitação anual é superior a $1.500 \mathrm{~mm}$, com temperaturas variando de $13{ }^{\circ} \mathrm{C}$ a $28{ }^{\circ} \mathrm{C}$ (Eiten 1972, Silva et al. 2008). 
A geomorfologia da região se insere no domínio morfoestrutural de Bacias e Coberturas Sedimentares Fanerozoicas e na unidade de Planaltos em Estrutura Sedimentar Concordante (IBGE 2010). O relevo é organizado em patamares decrescentes em que se localizam os chapadões resultantes dos processos erosivos sobre os arenitos e basaltos da Bacia Geológica do Paraná (Ab’Sáber 1950). As áreas de aplainamento e dissecação fluvial dão origem a colinas amplas e drenagem de baixa densidade (Arruda et al. 2008). Ocorrem também as formas de mesas sedimentares que são encontradas com frequência e se caracterizam por morros tabulares de bordas escarpadas e drenagem de média densidade e vales encaixados.

A geologia da área é apresentada na Figura 8 (EIBH 2005). A base dos dados geológicos foi obtida do acervo de Estudos Integrados de Bacias Hidrográficas (EIBH)_Sudoeste do Estado de Goiás na escala de 1:100.000. O objetivo desse estudo foi o aprimoramento do gerenciamento ambiental da região por meio de diagnósticos dos meios biótico, abiótico e antrópicos das bacias hidrográficas do estado, além da avaliação dos impactos ambientais advindos das instalações de hidrelétricas, e também a elaboração de medidas de compensação ambiental para mitigação dos impactos causados pela implementação dos empreendimentos hidrelétricos.

Concentrada na porção noroeste da área de estudo a Formação Aquidauana (3,07\%) é composta por arenitos com intercalações pelíticas que apresentam uma coloração vermelha devido à rocha matriz (Oliveira \& Campos 2012).

A Formação Botucatu $(17,57 \%)$ localizada na parte noroeste da área de estudo são derivadas de áreas de relevo pouco acentuado, apresenta materiais oriundos de rochas cristalinas e sedimentares preexistentes, e depositados em bacia estável, com transporte relativamente prolongado e fortemente retrabalhados por abrasão seletiva em condições áridas (Fernandes et al. 2008).

A Formação Serra Geral $(12,32 \%)$ é representada por derrames basálticos derivados do evento de extravasamento intracontinental de lavas, que ocorreram nos estágios de ruptura do Gondwana e à abertura do Atlântico Sul. Os basaltos da Formação Serra Geral ocorrem sobre formas de diques e soleiras intrudidas nos sedimentos da bacia (Milani \& Thomaz Filho 2000).

O Grupo Bauru está presente na maior parte do território da bacia, representado pelas Formações Adamantina (38,20\%) e Marília (2,90\%) que são compostas pelos arenitos e conglomerados (Soares et al. 1980). É característico dessa formação geológica nódulos de 
carbonatos de cálcio, que aparecem concentrados em níveis ou zonas (Dal' Bó \& Basilici 2011). A ocorrência de nódulos de carbonatos de cálcio indica que o ambiente deposicional da Formação Marília está relacionado aos paleoambientes flúvio-lacustres e aluviais, com a presença de planícies de inundação (Fernandes \& Coimbra 1996).

Na porção noroeste da área de estudo há o predomínio de sedimentos areno-argilosos da Formação Cachoeirinha $(14,41 \%)$ que se constitui basicamente de sedimentos arenoargilosos inconsolidados, vermelhos, argilitos cinza com estratificação incipiente e arenitos mal classificados com níveis decimétricos e lenticulares de conglomerados (Lacerda Filho et al. 1999), há também a ocorrência de Coberturas Quaternárias que incluem os Aluviões $(2,22 \%)$ e as Coberturas Arenosa Indiferenciada (7,46\%) que são constituídas, principalmente, por areia, argila e cascalho (Almeida et al. 2006).

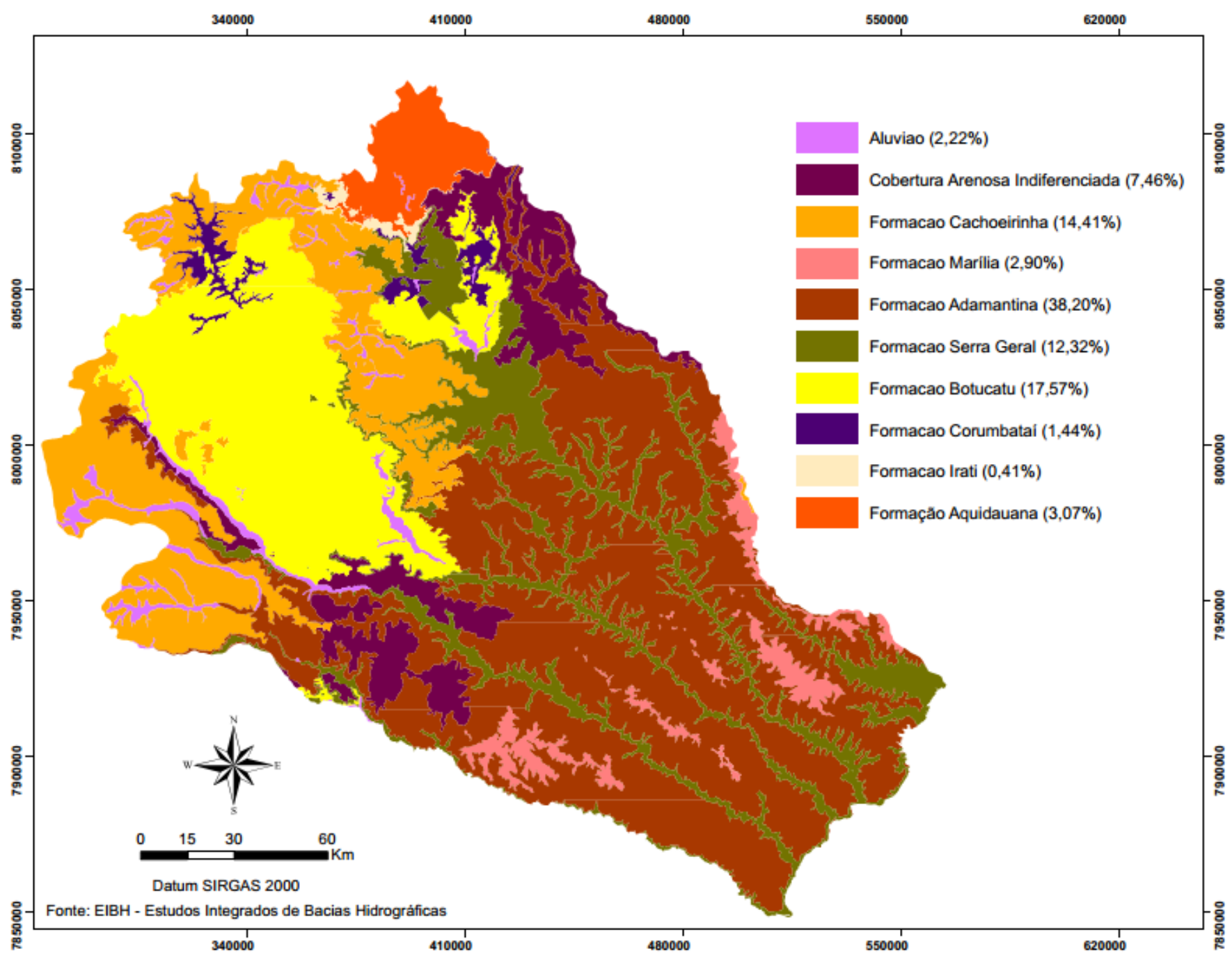

Figura 8. Geologia da área de estudo. Fonte: EIBH (2005). 
Em razão da grande abrangência de formações geológicas e outros fatores pedogenéticos, a região possui diferentes classes de solos, das quais predominam Latossolo Vermelho-Amarelo e Latossolo Vermelho que são associados a relevo predominantemente plano (Arruda et al. 2008) e caracterizados por serem solos profundos e bem drenados que possibilitam a utilização em culturas anuais, perenes, além, de pastagens. Sobre os Latossolos Vermelhos Distroférricos são encontradas áreas extremamente férteis, devido a processos geológicos de milhões de anos de decomposição de rochas basálticas pertencentes à Formação Serra Geral, em que esses processos resultaram em solos de coloração vermelho-arroxeada, compostos por magnetita e óxido de ferro (Ker 1997).

Também associados aos basaltos, nos fundos de vale são encontrados solos de elevada fertilidade como os Chernossolos, que apresentam alto potencial agrícola devidas às características químicas e físicas de solos eutróficos e profundos, e os Neossolos Flúvicos reconhecidos pelo grande potencial agropecuário devido possuírem textura média e apresentarem boa drenagem (MACROZAEE-GO 2014b).

Dentre as classes de Argissolos os mais abundantes são os Vermelho-Amarelos que tem ocorrência em áreas de relevos movimentados e dissecados, sendo necessária a correção desses solos para obtenção de produtividade agrícola signifitiva. Tambem são encontrados os Neossolos Litólicos e Cambissolos, sendo solos pouco intemperizados e concentrados em áreas de relevos acidentados (MACROZAEE-GO 2014b).

\subsection{MATERIAL E MÉTODOS}

\subsubsection{Mapeamento das Unidades de Relevo}

Foram utilizadas cenas da missão Shuttle Radar Topography Mission (SRTM) com resolução de 90 m, das folhas cartográficas (SE-22-V-C, SE-22-V-D, SE-22-X-C, SE-22Y-A， SE-22-Y-B， SE-22-Y-C， SE-22-Z-A， SE-22-Y-D， SE-22-Z-C) adquiridas diretamente da página eletrônica do Projeto Brasil em Relevo da Embrapa Monitoramento por Satélite (http://www.relevobr.cnpm.embrapa.br) para delimitação das unidades de relevo da área de estudo.

Foi realizado um mosaico com as cenas SRTM, e por ser um dos métodos mais utilizados devido a possibilidade de aumentar o realce de contraste, essas cenas foram dispostas em composição colorida R/G/B (Red/Green/Blue) com as variáveis morfométricas de curvatura máxima, declividade e curvatura mínima, respectivamente.

As derivadas das variáveis de primeira ordem (declividade) e de segunda ordem 
(curvatura) extraídas do SRTM são componentes básicos para a análise do relevo (Ehsani \& Quiel 2008). A declividade é expressa em forma de graus ou porcentagem e consiste na inclinação da superfície do terreno em relação ao plano horizontal, possibilitando a observação da transição das altitudes do terreno e das curvas de nível. A curvatura é a variável que define a orientação das vertentes e permite a divisão do relevo em áreas homogêneas (Valeriano 2008).

Os tipos de curvatura utilizados para avaliação das formas de terreno dependem da declividade da região classificada, ou seja, da natureza do relevo que está sendo modelado (Young 1978). Em áreas de declividade menos acentuada, com relevo mais suave, no qual se insere a área de estudo, são utilizadas as curvaturas máxima e mínima que permitem análise de maneira mais padronizada dos ambientes (Wood 1996).

Para delimitação dos compartimentos de relevo efetuou-se a classificação supervisionada utilizando o método de Máxima Verossimilhança (MaxVer), que considera a ponderação das distâncias entre as médias dos valores dos pixels das classes. Esta técnica assume que todas as bandas têm distribuição normal e calcula a probabilidade de um dado pixel pertencer a uma classe específica (Richards 1999).

A coleta das amostras de treinamento foi efetuada com a análise dos padrões de respostas de cor, forma e textura homogêneas nas imagens R/G/B, dando origem as classes das unidades de relevo e a transformação dessas classes em vetores. Por ser um método de classificação semi-automática, a classificação supervisionada demanda a pós-classificação, na qual foi necessária a aplicação do filtro majoritário para eliminação dos ruídos de classificação, além da inspeção visual, que necessitou a vetorização digital em tela na escala de 1:100.000 por meio da interpretação visual que considerou os aspectos de cor, forma e textura, e também o auxílio da chave de identificação de unidades geomorfológicas apresentada na Tabela 1, em composição colorida de dados altimétricos realizado por Sena-Souza (2013) para verificação de possíveis confusões de classes.

A nomenclatura das unidades de relevo foi realizada em níveis hierárquicos, conforme proposta do IBGE (2009) em que são definidos os domínios morfoestruturais (primeiro nível), as regiões geomorfológicas (segundo nível), as unidades geomorfológicas (terceiro nível) e os modelados (quarto nível). Neste estudo, foi utilizado o táxon de terceiro nível hierárquico, as unidades geomorfológicas que abrangem áreas de Planaltos Residual, Planalto Parcialmente Denudado, Mesa, Frente de Recuo Erosivo, Rampas de Colúvio, Depressão Intraplanáltica, Depressão Dissecada e Planície Fluvial. 
Tabela 1. Chave para identificação de unidades geomorfológicas em composição colorida R/G/B (Curvatura Máxima/Declividade/Curvatura Mínima). Fonte: Adaptado Sena-Souza (2013).

\section{Unidades Geomorfológicas}

Depressão Dissecada
Cor roxa no topo do relevo e tons de azul nas porções inferiores, relevo suave ondulado a ondulado com declividade média a forte, e altitudes baixas.

\section{Padrão de Cores na Composição Colorida RGB}

Depressão Intraplanática

Apresenta cores vermelhas, com bordas amarelas. São originadas em razão da erosão de antigas áreas planas, associadas as redes de drenagem.

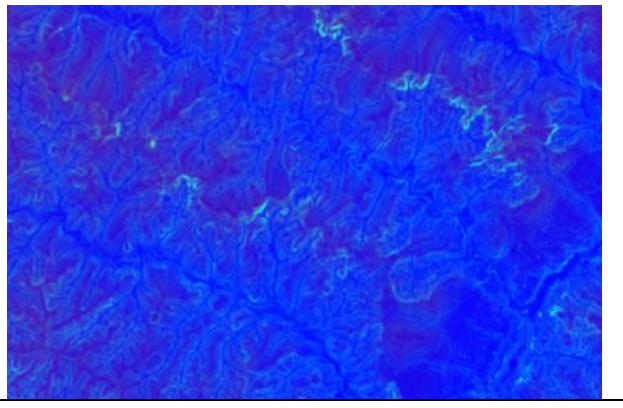

Frente de Recuo Erosivo
São caracterizados pela cor amarela e por circundarem áreas planas em tons vermelhos. Possui declive acentuado que caracteriza relevo bastante íngreme com compartimentos individualizados, atingindo $850 \mathrm{~m}$ de altitude.

Cor vermelha com altitudes que variam de $550 \mathrm{~m}$ a $700 \mathrm{~m}$ e declividade baixa, são caracterizadas por estarem circundadas pelas unidadades de Frente de Recuo Erosivo em tons amarelos e verdes.
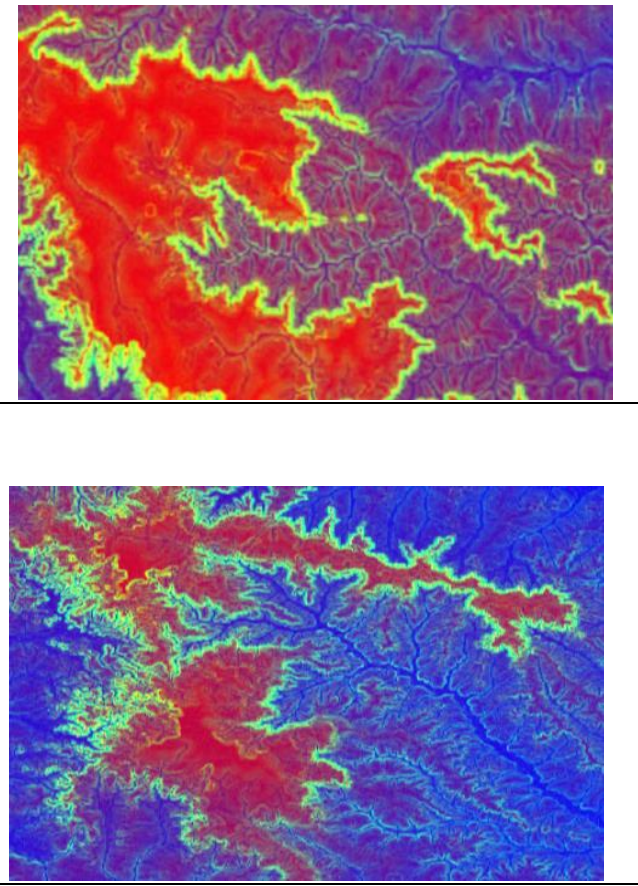
Planalto Parcialmente Denudado
Tonalidade roxa, com relevo plano a suave ondulado de altitudes elevadas que variam de $800 \mathrm{~m}$ a $100 \mathrm{~m}$.

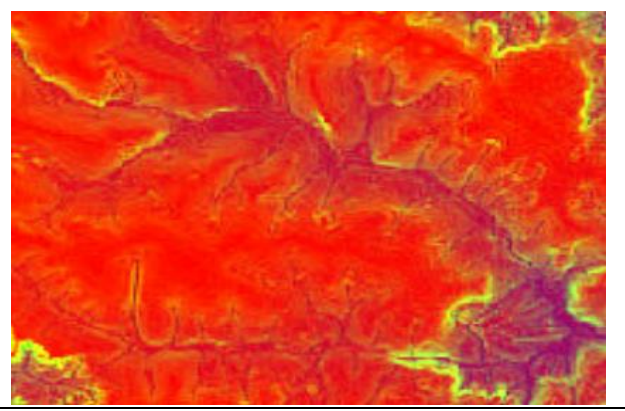

Planalto Residual

Coloração vermelha, caracterizada por relevo plano a suave-ondulado e pela preservação do relevo, sendo as unidades de relevo mais antigas.

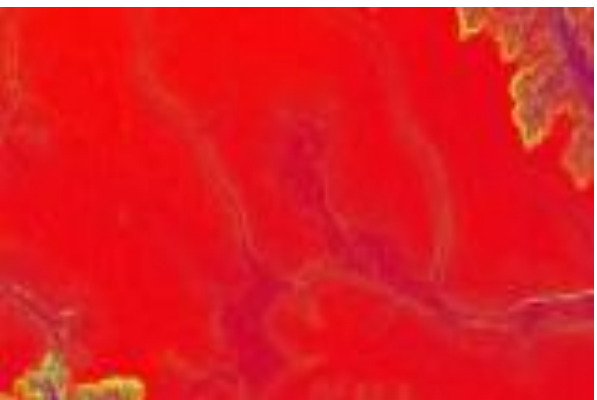

Planície Fluvial

Com tonalidade azul escuro, esse relevo é moldado no decorrer dos principais cursos d'agua, com áreas de menores altitudes e declividade em relação as demais unidades de relevo

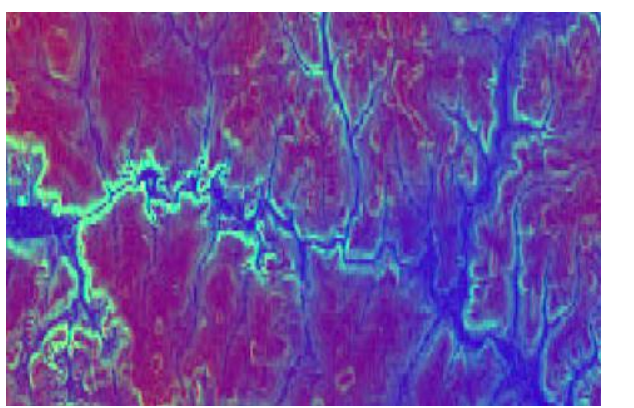

Rampa de Colúvio

Cor Rosa escuro, que representa a transição de áreas planas elevadas (vermelha), para áreas dissecadas de menores altitudes (roxo). Com formação associada as drenagens, o grau de dissecação das Rampas de Colúvio aumentam à medida que se aproximam dos cursos d'água.

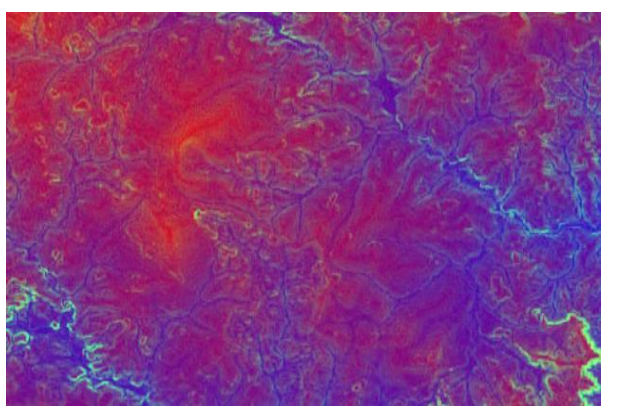




\subsubsection{Integração dos Dados}

Para representação do comportamento da variação de distribuição das características morfométricas de cada unidade de relevo e para avaliação das condições topográficas da ocupação territorial da área de estudo, foram confeccionados histogramas de frequência de altimetria e declividade, que são utilizados para a análise integrada dos dados altimétricos.

As assinaturas de uso da terra foram confeccionadas conforme organização das unidades de relevo, das mais antigas às mais recentes, sendo as áreas com menor grau de dissecação as unidades mais antigas, e as de maior grau de dissecação as mais recentes. As assinaturas de uso da terra foram geradas pela seguinte equação:

Frequência Relativa $(\%)=($ Frequência Absoluta/Total de observações $) * 100$

A observação da variação altimétrica do relevo e da disposição dessas unidades na área de estudo, foi realizada por meio da elaboração de um perfil topográfico que teve como função auxiliar na visualização da disposição espacial das unidades geológicas em relação a distribuição dos compartimentos do relevo.

As informações obtidas do relevo e sua relação com a geologia e uso e cobertura da terra possibilitou a análise integrada apresentada por meio de gráficos de distribuição da área das unidades geológicas e das classes de uso e cobertura do solo em cada unidade de relevo.

\subsection{RESULTADOS E DISCUSSÕES}

A partir dos procedimentos adotados foi possível gerar o mosaico das cenas SRTM e a composição colorida (Figura 9) para a extração das informações das variáveis morfométricas de altitude e declividade.

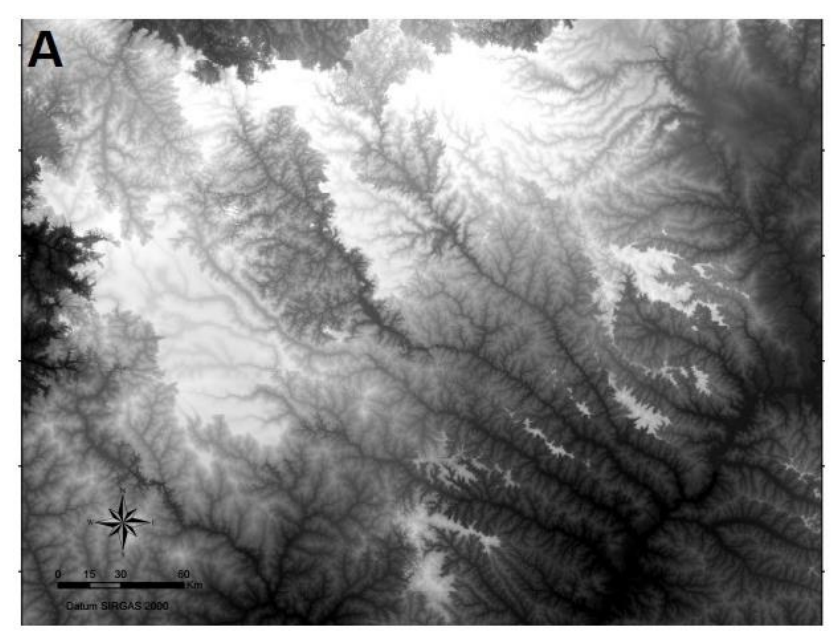

Figura 9. Mosaico das cenas SRTM (A) Máxima/Declividade/Curvatura Mínima) (B)

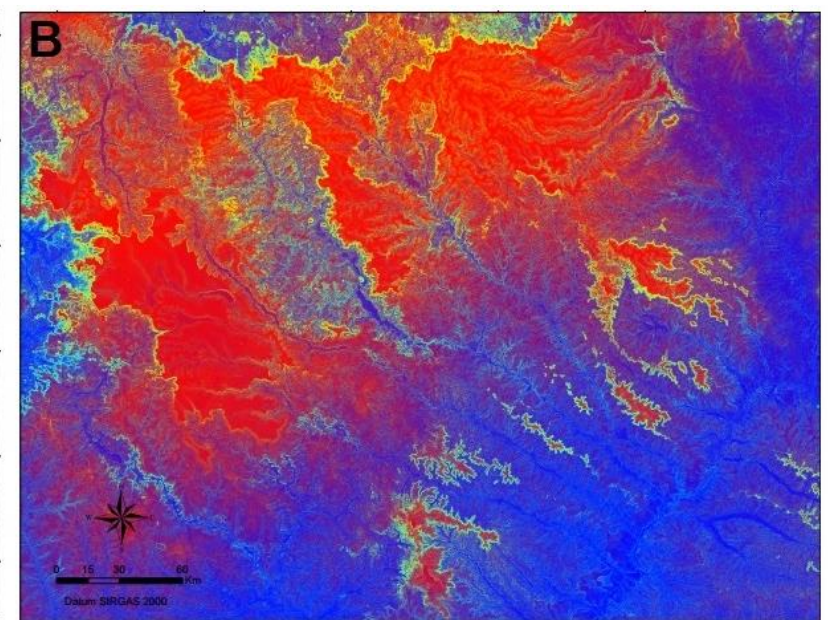

22

\footnotetext{
Máxima/Declividade/Curvatura Mínima) (B)
} 
O mapeamento do relevo possibilitou a identificação de oito unidades dentro da área de estudo (Figura 10), na sequência da evolução geomorfológica: Planalto Residual, Planalto Parcialmente Denudado, Mesa, Frente de Recuo Erosivo, Rampas de Colúvio, Depressão Intraplanáltica, Depressão Dissecada, e Planície Fluvial. Os Planaltos e as Mesas foram desenvolvidos no ciclo de aplainamento da superfície Sulamericana (King 1956). As Rampas de Colúvio e as Depressões foram desenvolvidas durante o ciclo de aplainamento Velhas (King 1956). 


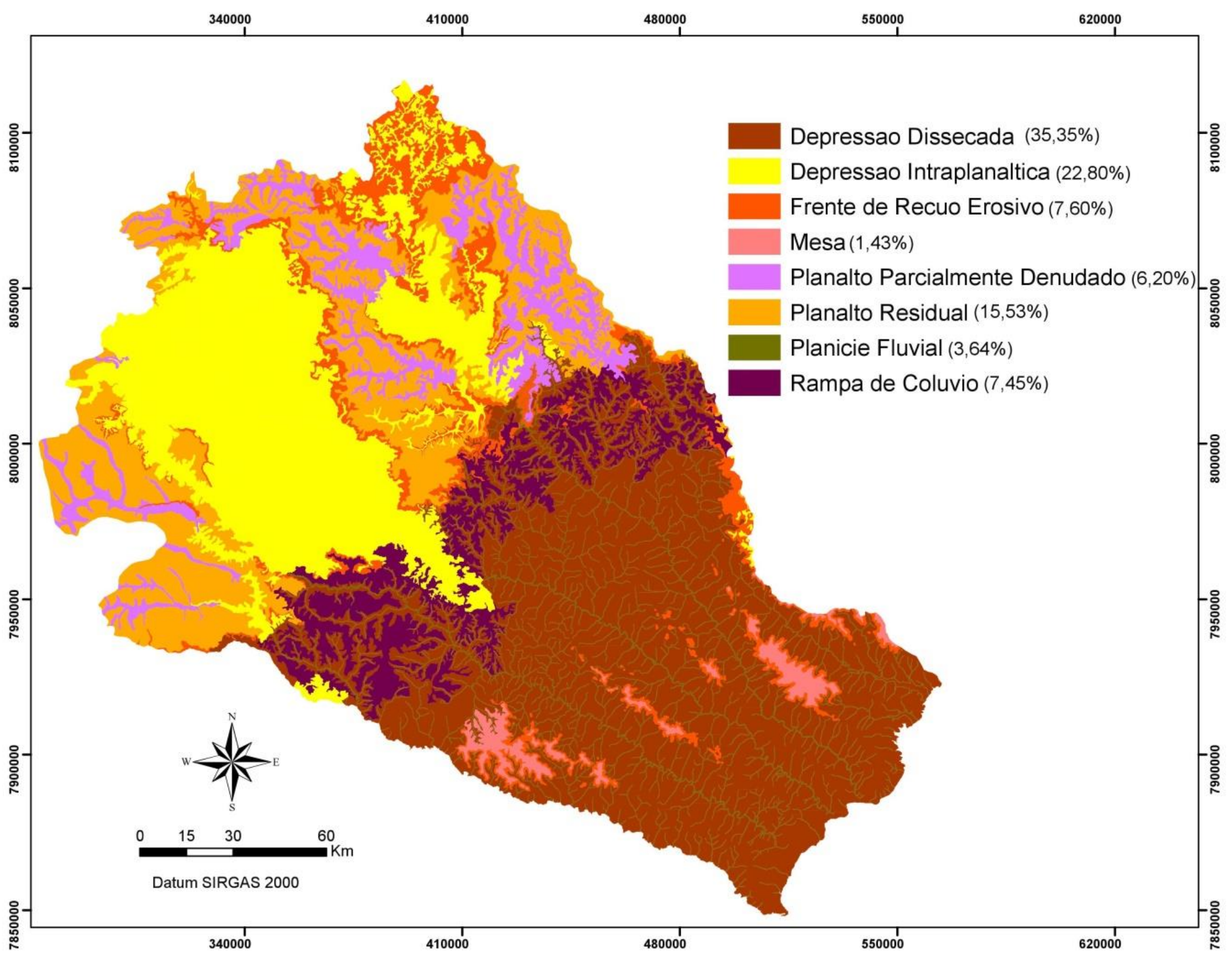

Figura 10. Mapa das unidades de relevo da área de estudo. 
Essas informações são importantes para compreensão da relação dessas variáveis morfométricas nas diferentes topografias do terreno que, de modo geral, se caracterizam por relevo plano a suave ondulado, com altitudes variando de 400 a $1.000 \mathrm{~m}$ (Figura $11 \mathrm{e}$ 12). As características morfométricas de altimetria e declividade de cada unidade de relevo estão apresentadas, por meio dos histogramas de frequência (Figura 13). São apresentadas as proporções das unidades geológicas em cada da unidade de relevo (Figura 14), uma vez que as unidades geológicas são sub-horizontais e, portanto, o afloramento dessas unidades está relacionado a variação das cotas topográficas, evidenciando que os compartimentos de relevo estão intimamente relacionados com a geologia da área de estudo.
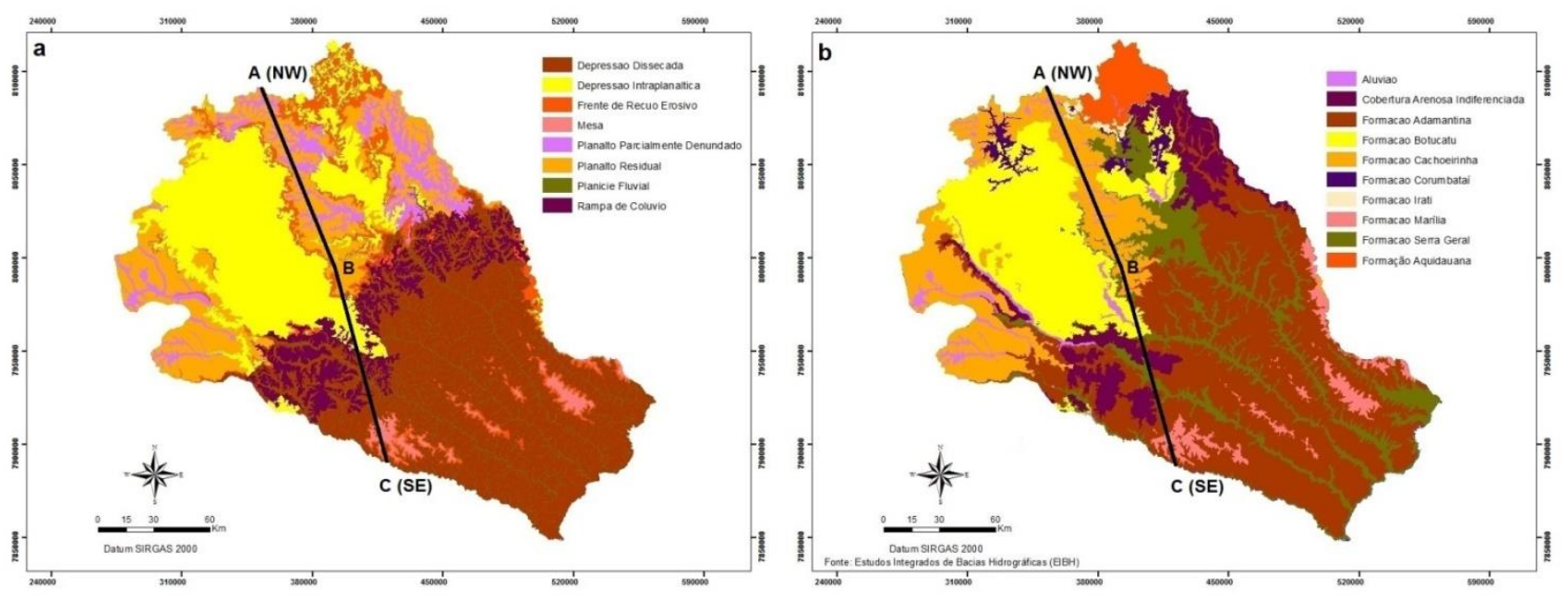

Figura11. Transecto do perfil topográfico A-B-C nas unidades de relevo (a) e nas formações geológicas (b) da área de estudo.

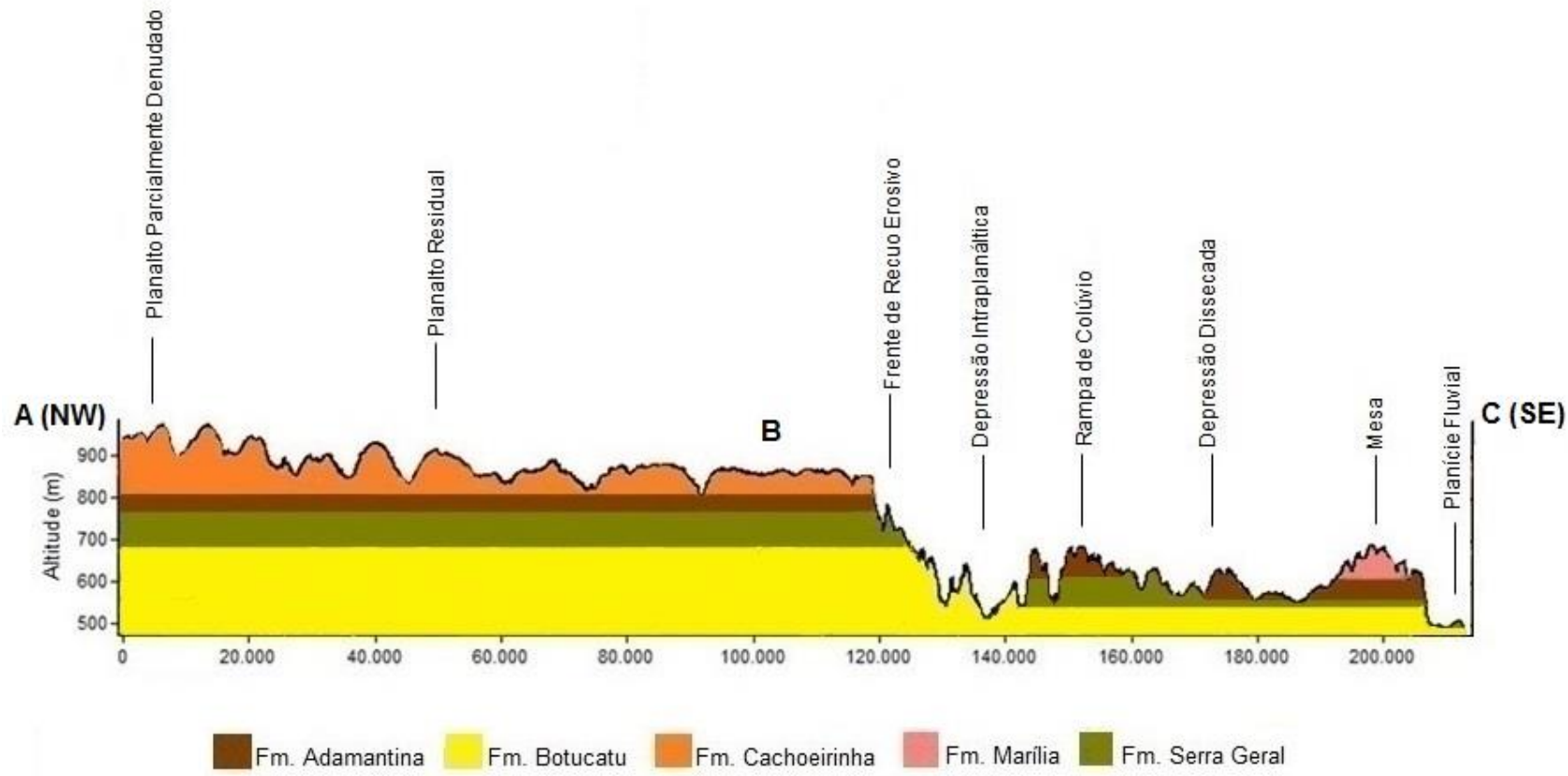

Figura 12. Perfil topográfico das unidades de relevo relacionadas com formações geológicas da área de estudo. 

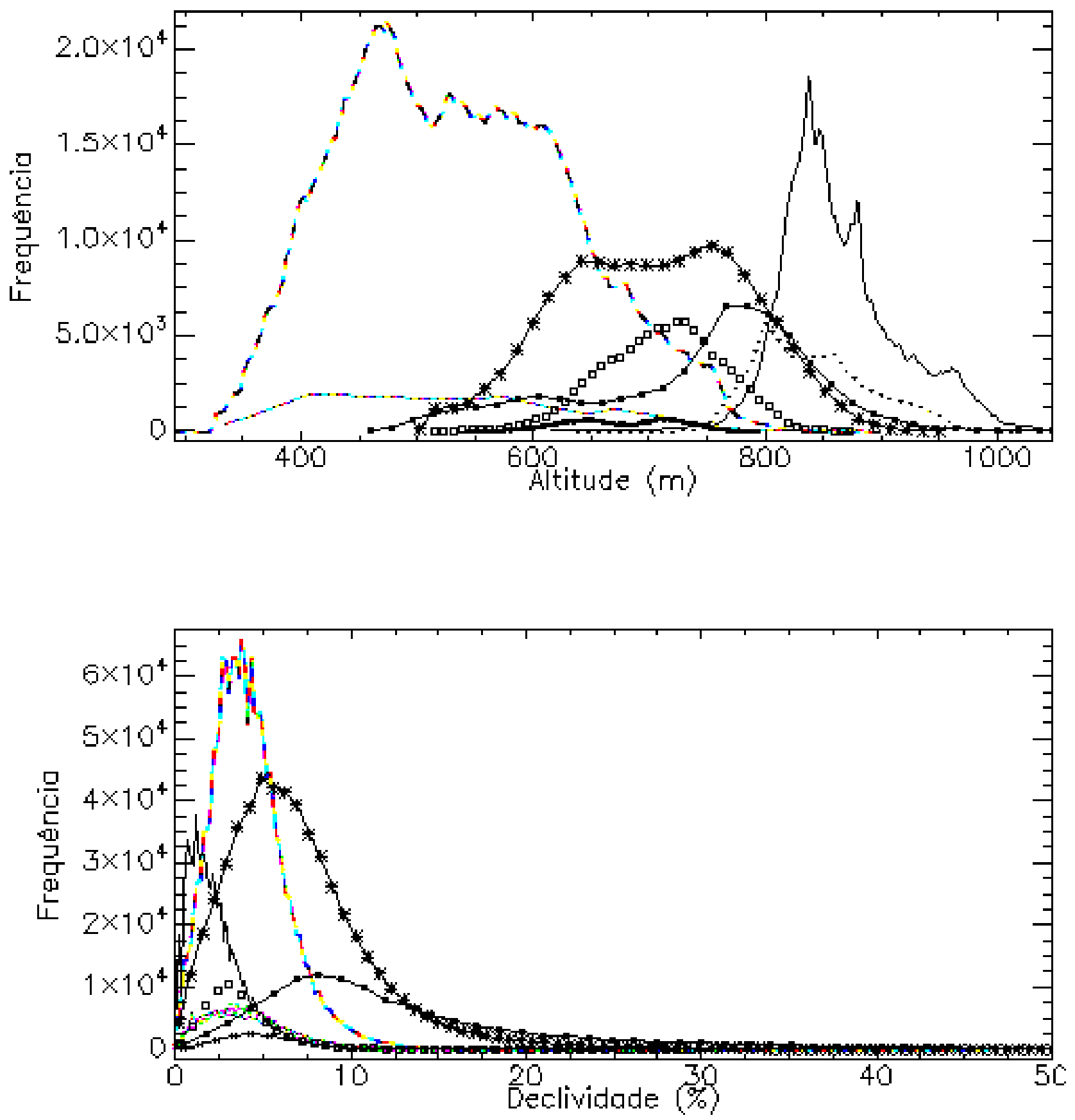

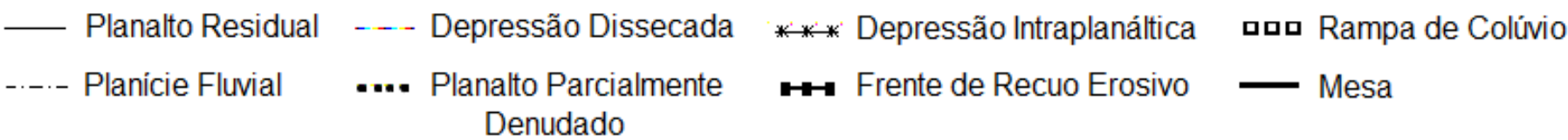

Figura 13. Histogramas de frequência de altimetria e declividade das unidades de relevo. 


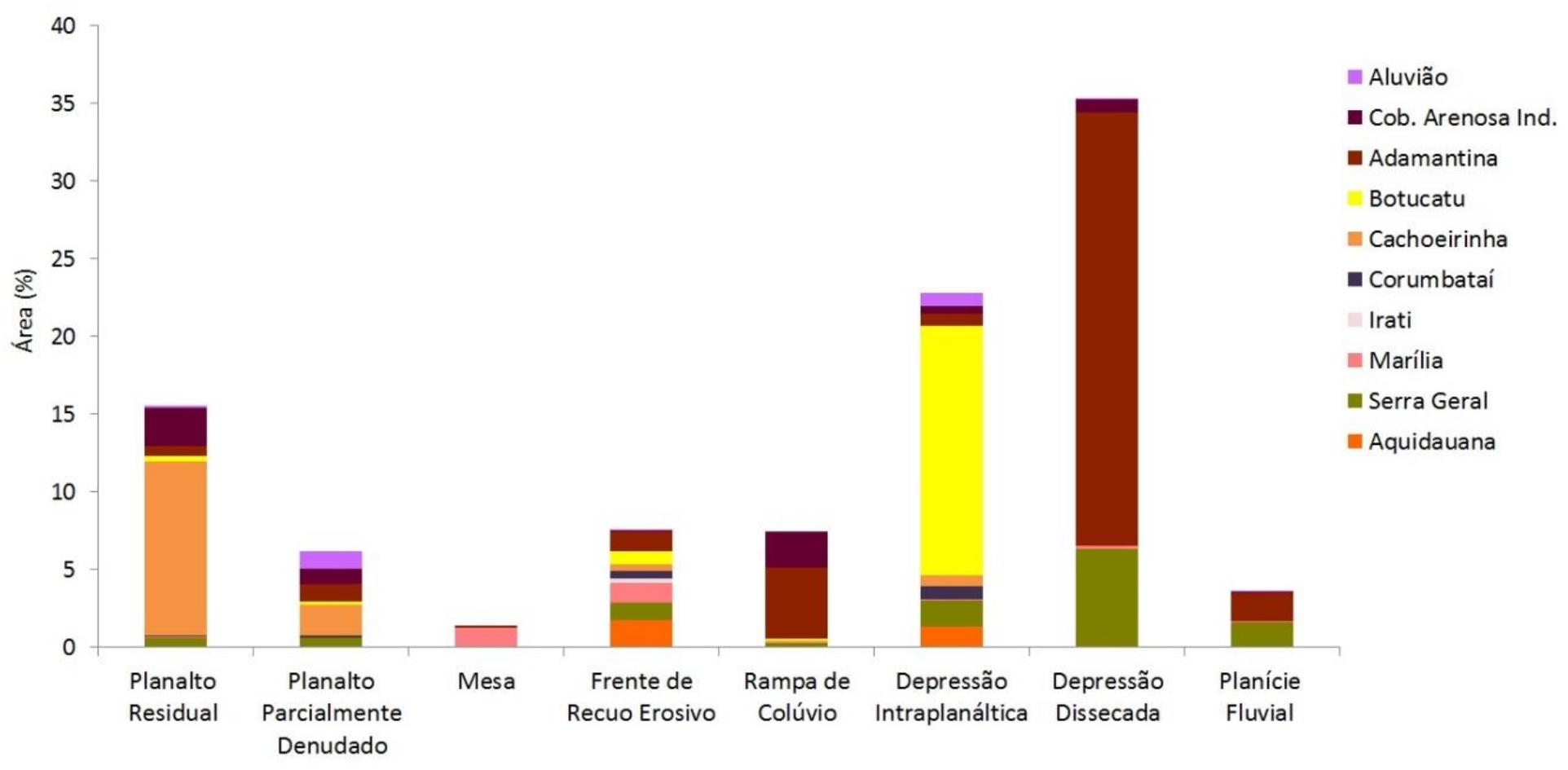

Figura 14. Gráfico representando a distribuição da área (\%) das unidades geológicas em cada unidade de relevo.

A Depressão Dissecada (35,35\%) é a unidade que possui maior distribuição na área de estudo, apresentando relevo suave ondulado a ondulado com declividade média a forte, e altitudes baixas, que caracteriza um dos compartimentos mais rebaixados. Essa unidade apresenta padrões de dissecação de médio a forte em razão dos arenitos cretáceos do Grupo Bauru que abrange a Formação Adamantina (27,86\%), constituída por arenitos finos, siltitos e argilitos dispostos em camadas de aspecto maciço ou plano-paralelos, e estratificações cruzadas de pequeno e médio porte.

Também sobre os arenitos do Grupo Bauru, são encontradas as unidades de relevo de Mesa $(1,43 \%)$ com altitudes que variam de $550 \mathrm{~m}$ a $700 \mathrm{~m}$ e declividade de $15 \%$, são caracterizadas por estarem circundadas pelas unidadades de Frente de Recuo Erosivo. As Mesas estão inseridas na Formação Marília (1,25\%) que se desenvolveu em embaciamento, repousando sobre a Formação Adamantina, e sobre os basaltos da Formação Serra Geral (Fernandes 1998), composta por arenitos grosseiros a conglomeráticos e calcários.

No decorrer dos principais cursos d'agua da região (Rio Paranaíba, Rio do Peixe, Rio Bonito, Rio Diamantino, Rio dos Bois e Rio Claro), são moldadas as unidades de Planícies Fluviais $(3,64 \%)$ que apresentam as menores altitudes em relação as demais unidades, e baixa declividade. Esses cursos d'água estão localizados na parte sudeste, em direção ao 
Rio Paranaíba, e estão sobre os basaltos de coloração cinza e negra da Formação Serra Geral $(1,63 \%)$.

As unidades de Planaltos Residuais $(15,53 \%)$ são constituídas de grandes chapadões suaves, bem delimitados (Ab’Sáber 1950) com relevo plano a suave-ondulado, concentradas na porção noroeste do território. Em relação a evolução geomorfológica, os Planaltos Residuais se caracterizam pela preservação do relevo, sendo as unidades de relevo mais antigas devido o grau de dissecação ser de menor intensidade. Quanto ao aspecto geológico, essa unidade é composta por depósitos sedimentares mais recentes, constituída de areias brancas, cinza, amarelas e avermelhadas, e argilas que são intercaladas com níveis conglomeráticos e laterizados da Formação Cachoeirinha $(11,20 \%)$.

A Depressão Intraplanáltica $(22,80 \%)$ localizada na porção noroeste, é originada em razão da erosão de antigas áreas planas, associadas as redes de drenagem. $\mathrm{O}$ grau de desenvolvimento da Depressão Intraplanáltica está relacionado com a presença de grandes drenagens e também por sua litologia da Formação Botucatu (16\%) composta de arenitos eólicos avermelhados de granulação fina a média com estratificações cruzadas de médio e grande porte, depósitos fluviais restritos de natureza areno-conglomerática e camadas localizadas de siltitos e argilitos lacustres. A Formação Botucatu é caracterizada por matérias derivados de áreas de relevo pouco acentuado, advindos de rochas cristalinas e sedimentares preexistentes, depositados em bacia estável, com transporte relativamente prolongado e fortemente retrabalhados por abrasão seletiva.

A Frente de Recuo Erosivo (7,60\%) apresenta declive acentuado que caracteriza relevo bastante íngreme com compartimentos individualizados, atingindo $850 \mathrm{~m}$ de altitude. Possui desenvolvimento sobre as rochas da Formação Aquidauana (1,72\%) que predominam arenitos com intercalações pelíticas (argilitos e folhelhos). Em menor proporção, as Frentes de Recuo Erosivos se desenvolvem nas Formações Adamantina $(1,27 \%)$, Marília $(1,24 \%)$ e Serra Geral $(1,19 \%)$.

As unidades de Planalto Parcialmente Denudado $(6,20 \%)$ se encontram em relevo plano com altitudes elevadas que variam de $800 \mathrm{~m}$ a $100 \mathrm{~m}$ e em relevo plano a suave ondulado. Estão inseridas nas unidades geológicas da Formação Cachoeirinha (2\%), Aluvião (1,13\%) e Formação Adamantina (1,08\%).

As Rampas de Colúvio (7,45\%) são a transição de áreas planas mais elevadas para áreas dissecadas de menores altitudes. Com formação associada as drenagens, o grau de 
dissecação das Rampas de Colúvio aumentam à medida que se aproximam dos cursos d'água. Desenvolvidas sobre a Formação Adamantina (4,53\%) e a Cobertura Arenosa Indiferenciada $(2,35)$, essas unidades são caracterizadas por apresentar textura arenítica que constituem solos arenosos.

O relevo é considerado um importante aspecto na compreensão da distribuição espacial das classes de uso e cobertura da terra da área de estudo. A gênese do relevo evidencia os padrões de uso e cobertura da terra, e a integração dessas informações é demonstrada pelas assinaturas das classes de uso e cobertura da terra (Figura 15). Essas assinaturas são utilizadas para auxiliar na identificação das potencialidades e limitações dos diferentes usos da terra atribuídos pelo relevo. São apresentadas as proporções de distribuição de área dessas classes de uso e cobertura da terra em cada compartimento de relevo (Figura 16). As informações de altitude e declividade de cada classe de uso e cobertura da terra são visualizadas, por meio dos histogramas de frequência (Figura 17).

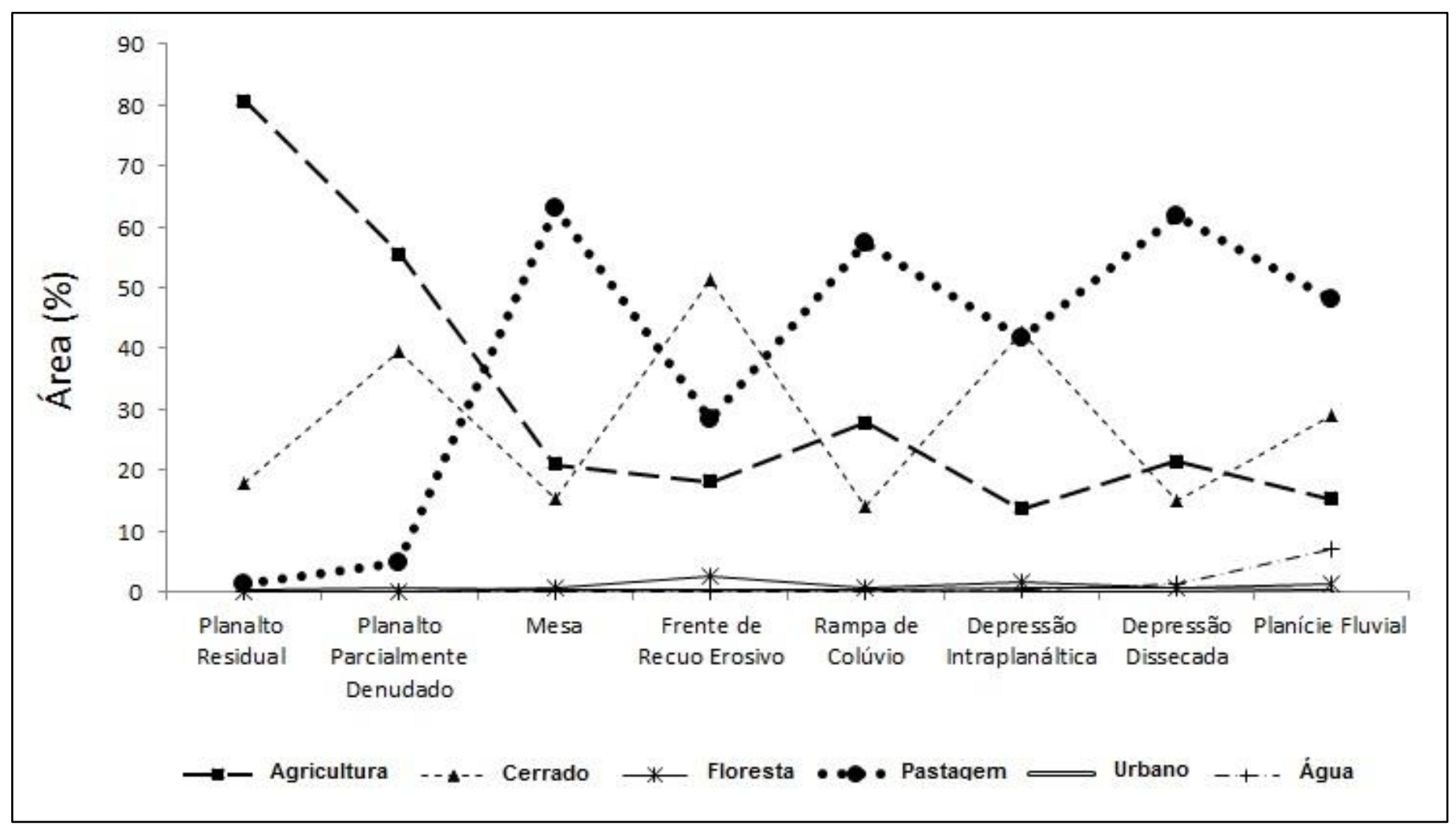

Figura 15. Assinatura de uso e cobertura da terra nas unidades de relevo. 


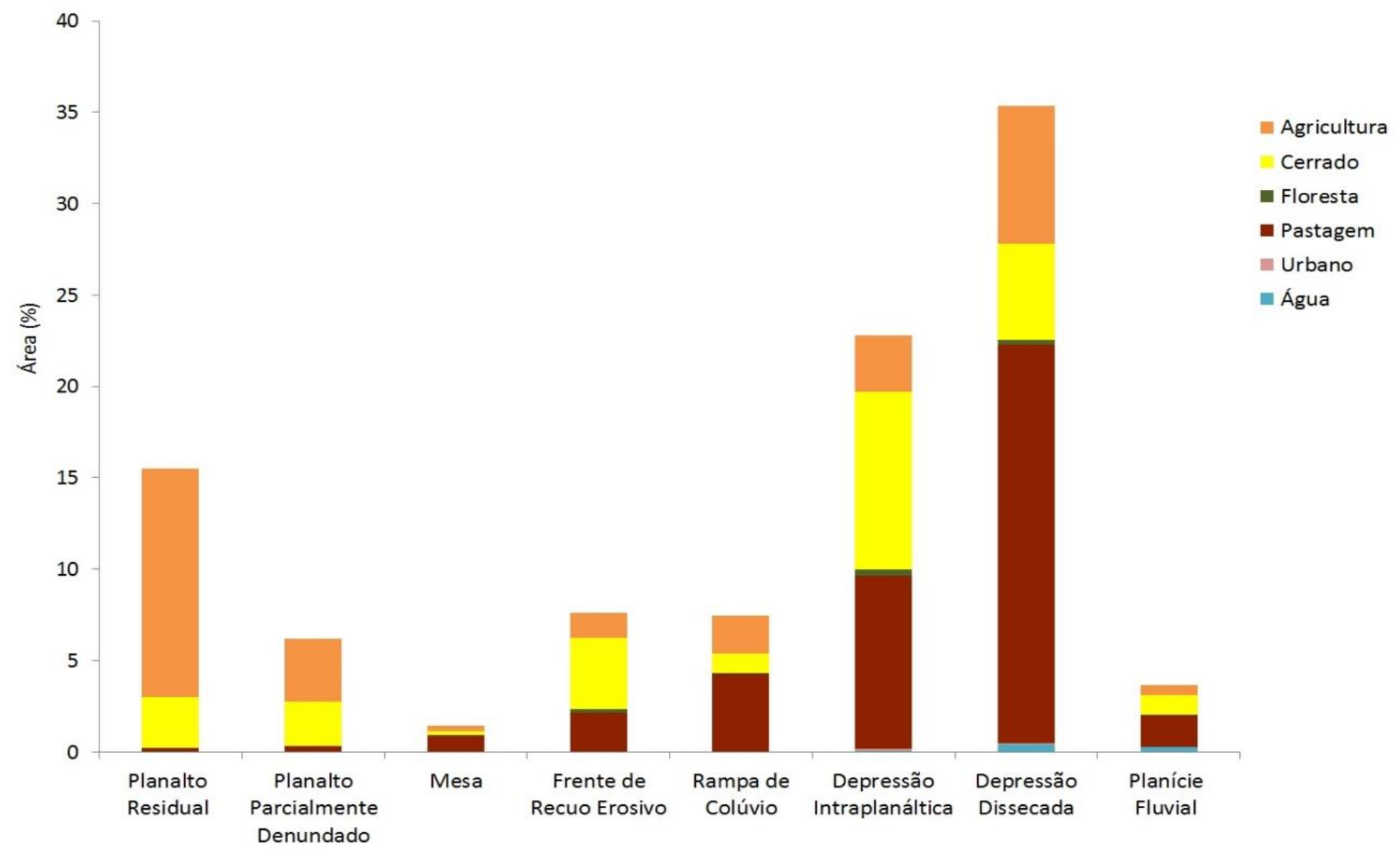

Figura 16. Gráfico representando a distribuição de área (\%) das classes de uso e cobertura da terra em cada unidade de relevo.

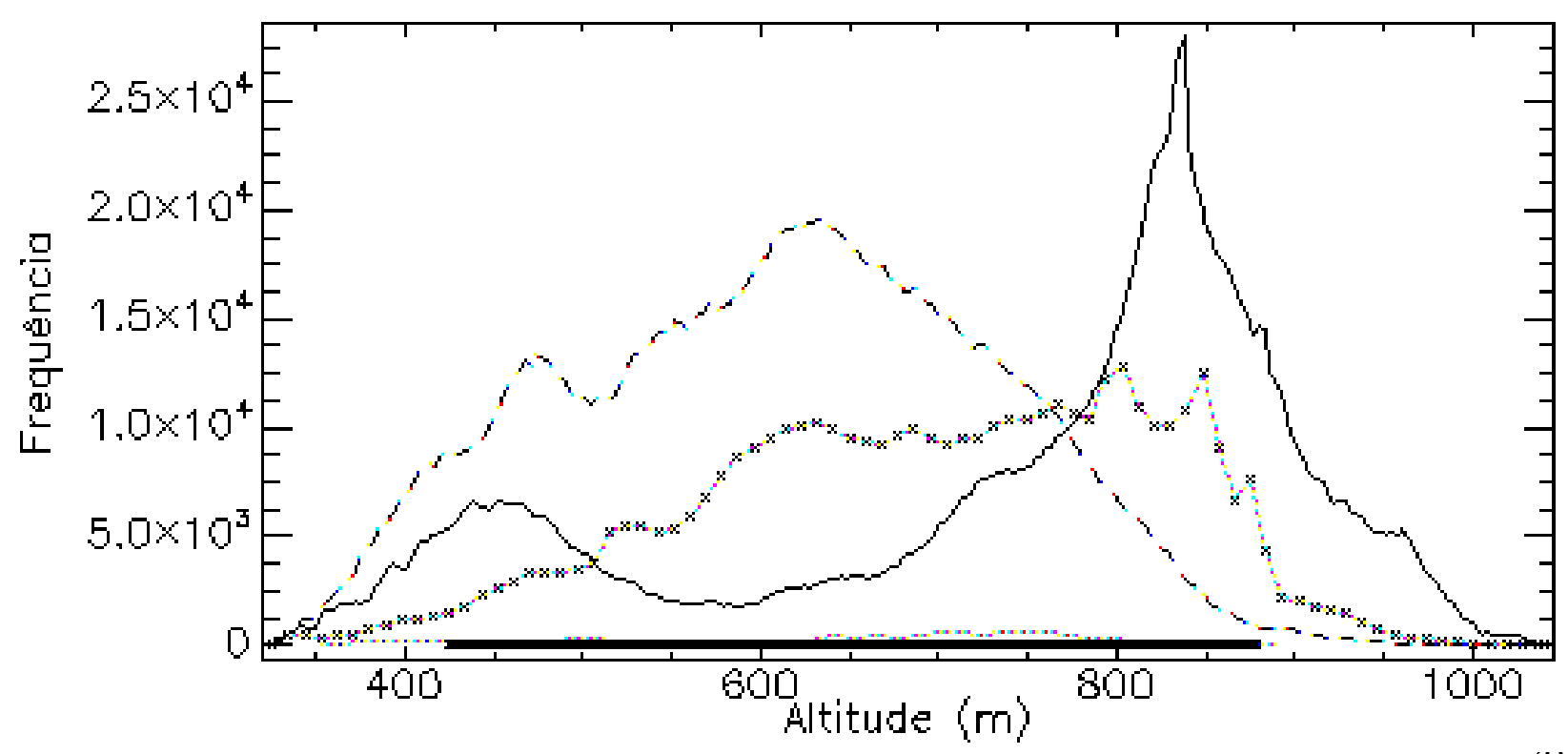




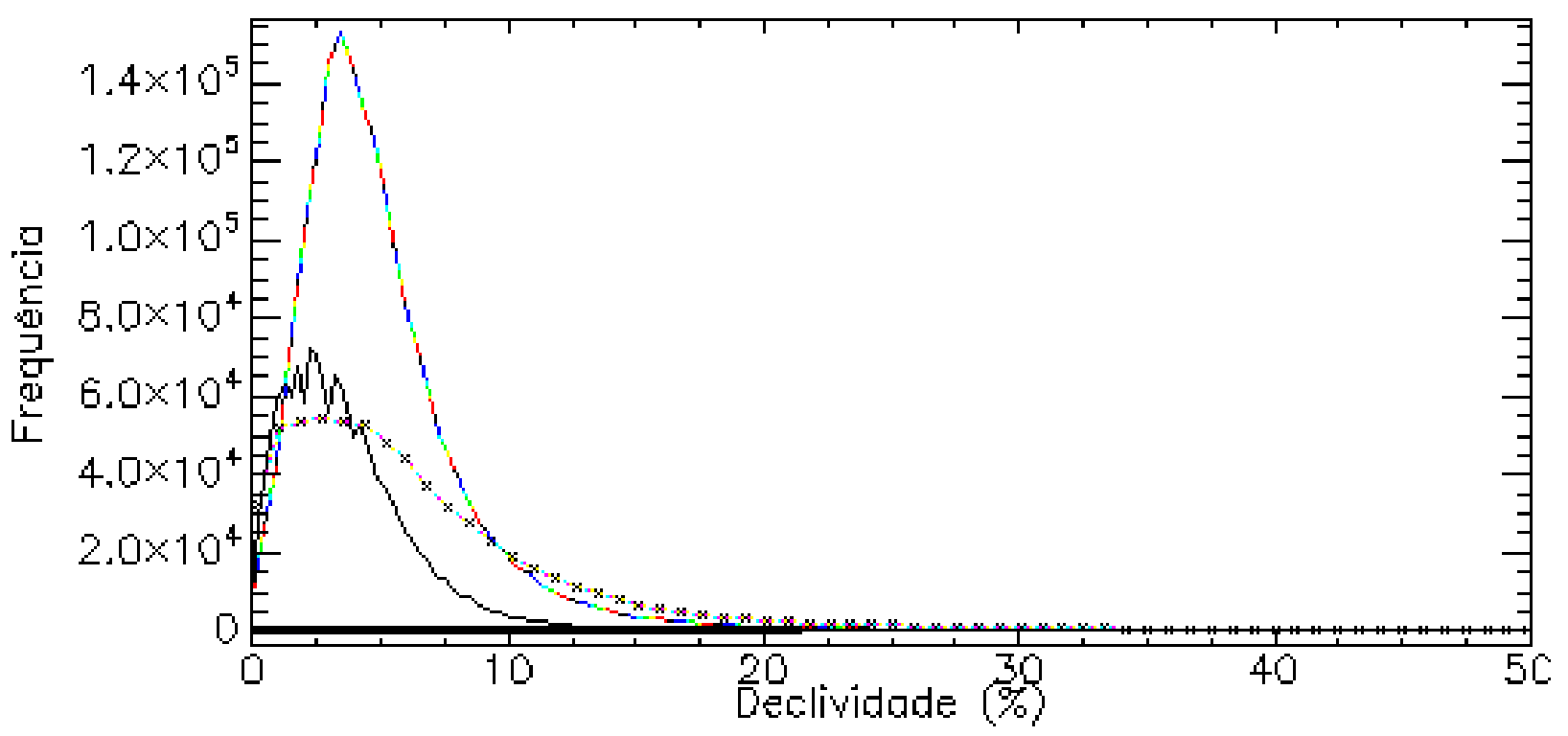

_ Agricultura $* * * \cdots *$ Cerrado Floresta Urbano

Figura 17. Histogramas de frequência de altimetria e declividade das classes de uso e cobertura da terra.

A assinatura do Cerrado (Figura 15) mostra um padrão em zigue-zague, indicando que entre um compartimento e outro da paisagem ocorrem rupturas, onde o Cerrado predomina, enquanto que nos relevos mais planos os outros tipos de uso são predominantes. As áreas de vegetação natural ocorrem geralmente em locais bem drenados, onde se insere o Cerrado, que ocorre em maior concentração na Depressão Intraplanáltica e na Frente de Recuo Erosivo, com relevo declivoso e altitudes medianas. As florestas representam pequenos fragmentos em função do uso intensivo da região.

A Frente de Recuo Erosivo é o relevo de maior declividade, sendo áreas de erosão das superfícies planas, configurando em divisor dos relevos mais antigos de altitudes elevadas para os mais recentes, com menores altitudes. Por ser uma forma de relevo acidentada, a Frente de Recuo Erosivo concentra grande parte da cobertura vegetal natural, que é preservada devido as dificuldades de acesso para mecanização da agropecuária na região. Apesar da relação existente entre as áreas de relevos mais íngremes e a distribuição da vegetação natural do Cerrado (Sano et al. 2008), foi observado, a partir de modelos de dinâmica da paisagem no bioma Cerrado (Ferreira et al. 2013) as tendências atuais e futuras de expansão antrópica nas próximas décadas até 2050, no qual evidenciou forte pressão para conversão desses remanescentes naturais para áreas de cultivo agrícola e de pastagem (Klink \& Machado 2005). Em especial, as pastagens que possuem maior 
adaptabilidade em relevos mais acidentados, localizadas em regiões menos favoráveis do que as áreas agrícolas, que necessitam de regiões planas e suaves onduladas (Silva et al. 2013a).

Os Planaltos e Mesas com altitudes elevadas são caracterizados por serem as unidades de relevo mais preservadas e estáveis em função da baixa declividade, e pela cobertura de solos muito intemperizados. O relevo plano e contínuo, além dos solos profundos e bem drenados constituem os principais condicionantes do uso agrícola na área de estudo. A agricultura é a classe de maior porção na unidade de Planalto Residual, sobre os Latossolos Vermelhos, concentrada na porção norte e noroeste de maiores altitudes, e com fragmentos menores nos demais compartimentos de relevo. O processo de ocupação da agricultura foi iniciado nas áreas de relevo mais plano, em solos de textura média e argilosa (Ferreira et al. 2009).

A produção de grãos, como soja e milho se destacam na região devido a facilidade na mecanização agrícola nas áreas planas que apresentam maiores condições hídricas, e melhores técnicas de cultivos dos solos (Machado et al. 2004). A agricultura exercida em maior parte na área de estudo é do tipo plantio convencional, no qual são necessários grandes volumes de insumos, e investimentos em desenvolvimento tecnológico para aumento da escala de produção (Carneiro et al. 2013). Esse modo de cultivo intensivo, por necessitar de recursos financeiros elevados devido a alta produtividade obtida, faz com que o produtor agrícola ao observar que o investimento realizado não gerou o retorno em curto prazo de tempo, abandone a área de cultivo e passe a ocupar outros locais com o mesmo processo de ocupação anterior, que ao longo do tempo acarreta na incidência de erosões, assoreamento dos cursos d'água e perda de solos (Rezende 2003). Nesse sentido, o planejamento das atividades na agricultura, nessas áreas, requer a utilização dos aspectos de organização dos padrões de paisagem, como a dinâmica espacial e temporal do uso da terra.

As Depressões são áreas de altitude baixas e possuem formas planas e convexas devido a atuação dos processos de erosão durante longo período. Na Depressão Intraplanáltica, em que o relevo apresenta forte declividade, a vegetação natural se apresenta como a cobertura predominante em porção de área. Nas Depressões Dissecadas com relevo suave ondulado e solos de textura arenosa se insere em grande parte o cultivo de pastagem. 
As pastagens cultivadas estão associadas, em maior parte, às áreas de relevo descontínuos com limitação à mecanização, no qual se insere as Depressões Dissecadas, onde são encontradas grandes extensões de solos arenosos, localizados na porção sudeste das bacias hidrográficas. As áreas de pastagens possuem o máximo de ocupação também nas Mesas e Rampa de Colúvio, sendo áreas de relevo plano a suave ondulado. As Rampas de Colúvio são as formas de relevo localizadas na base de vertentes e estão associadas a antigos processos de deposição de sedimentos. Nessa unidade de relevo, predomina o cultivo em pastagem e em menor proporção a agricultura. Com distribuição de área reduzida nas Depressões Intraplanálticas de relevo ondulado, as porções de pastagem possui desenvolvimento sobre os Cambissolos e os Neossolos Quartzarênicos.

A conversão das pastagens nativas para cultivadas (Sano et al. 2001) aumentou significativamente a produção de carne na região, no entanto, a forma como atualmente é realizado o manejo dessas áreas ocasiona a perda na produtivdade de pecuária ao longo do tempo, acarretando grande prejuízo para a fertidade dos solos, além da ocorrência de doenças e pragas (Barcellos 1996). O sobrepastejo, também se configura como uma das principais causas da redução dessa produtividade, em que se verifica dificuldade na percepeção dos produtores dos danos ambientais e econômicos, causados pela prática do sobrepastejo (Brossard \& Barcellos 2005), que origina pastagens degradadas e improdutivas. Diante deste cenário, se observa que o manejo adequado das pastagens é a solução mais eficiente para atingir maior produtividade dessas áreas.

As áreas de Planície Fluvial com relevo de menor altitude e baixa declividade representam a evolução mais recente das unidades de relevo associados aos cursos d'água. Inserida nas áreas de Planícies Fluviais e de Depressão Dissecada, a classe de água abrange o Rio do Peixe, Rio Corrente, Rio Claro e Rio Doce que desaguam no Rio Paranaíba. As potencialidades dessas bacias hidrográficas consistem nas atividades agrícolas como a produção de soja e milho, e nas pastagens cultivadas. No aspecto agroindustrial apresenta uso expressivo em usinas sucroalcooleiras com uso da água em irrigação de áreas adjcentes, e nos processos industriais internos (CBH Paranaíba 2016).

A classe urbana é bastante reduzida, sendo a classe de menor extensão territorial da área de estudo, está inserida nos municípios de Jataí e Mineiros com fragmentos nas Depressões Intraplanálticas e Planaltos Parcialmente Denudados. 


\subsection{CONCLUSÕES}

A utilização de dados SRTM na extração das variáveis morfométricias para delimitação das diferentes unidades de relevo da área de estudo, mostrou ser um método bastante eficiente para análise das formas do terreno. O emprego dessa metodologia tem sido amplamente utilizado na compartimentação geomorfológica (Hermuche et al. 2002, Panquestor et al. 2002, Borges et al. 2007, Lima et al. 2009, Castro et al. 2010a, Castro et al. 2010b, Lima et al. 2010, Passo et al. 2010a, Passo et al. 2010b, Sena-Souza et al. 2013, Mendes 2015), demonstrando que esta abordagem se torna, cada vez mais, consolidada na obtenção de informações acerca das condições topográficas do terreno.

O procedimento adotado para o mapeamento do relevo possibilitou a identificação de oito unidades de relevo na área de estudo. As unidades de maior concentração são a Depressão Dissecada (35,35\%), Depressão Intraplanáltica (22,80\%), Planalto Residual (15,53\%), Frente de Recuo Erosivo (7,60\%), Rampas de Colúvio (7,45\%), Planalto Parcialmente Denudado (6,20\%), Planície Fluvial (3,64\%) e as Mesas (1,43\%). Os relevos que apresentam maiores altitudes são os Planaltos Residuais e os Planaltos Parcialmente Denudados, e os de altitudes menores são as Planícies Fluviais e as Depressões Dissecadas.

Os compartimentos de relevo apresentam integração em maior parte de suas áreas com as unidades geológicas da área de estudo, sendo a Depressão Dissecada e a Rampa de Colúvio associadas com a Formação Adamantina, a Depressão Intraplanáltica com a Formação Botucatu, o Planalto Residual e o Planalto Parcialmente Denudado com a Formação Cachoeirinha, a Frente de Recuo Erosivo com a Formação Aquidauana, a Planície Fluvial com a Formação Formação Serra Geral, e a unidade de Mesa com a Formação Marília.

Os usos e cobertura da terra nas unidades de relevo demonstraram que nas áreas de altitudes elevadas e relevo plano, como os Planaltos Residuais, são encontradas as atividades de agricultura com produção de grãos. O modo de ocupação agrícola que atualmente ocorre na área de estudo, demanda por planejamentos nos sistemas de produção, que inclua os fatores de organização dos padrões da paisagem, como a análise da dinâmica espacial e temporal do uso da terra.

Na Depressão Dissecada, a maior unidade de relevo na área de estudo, com forma de relevo ondulado e baixas altitudes, predominam as pastagens cultivadas, que ao longo do tempo, a forma de cultivo em diversos locais acarretou na degradação dessas áreas, devido 
o sobrepastejo. Desse modo, se observa que o manejo adequado é a solução mais eficiente para atingir maior produtividade das pastagens da região.

Nos relevos declivosos e descontínuos, o uso é mais restrito e a cobertura da terra é dominada pelo cerrado, no entanto, esses remanescentes naturais, estão sobre forte pressão para conversão em áreas de agricultura e pecuária.

A integração do relevo com as informações de geologia, uso e cobertura da terra são essenciais para conhecimento dos padrões da paisagem, corroborando com a utilização do relevo como suporte para os estudos de potencialidade e limitações de uso no contexto da paisagem. 


\section{CAPÍTULO 3 - CONSIDERAÇÕES FINAIS}

O conhecimento acerca das relações entre o relevo e o uso e cobertura da terra, evidencia que a ocupação do Cerrado é condicionada por características ambientais regionais de padrões de relevo. Esta abordagem subsidia a gestão dos recursos naturais e o planejamento territorial, com a utilização do relevo como elemento fundamental na análise espaço-temporal da paisagem.

As variáveis morfométricas de declividade e altimetria são fatores de potencialidades para os diferentes usos e cobertura da terra. Em áreas com usos da terra em agricultura e pecuária, os gastos de energia na realização dessas atividades, são aumentados ou reduzidos, em função desses aspectos de relevo. Dessa forma, o mapeamento das unidades de relevo, contribui na identificação das potencialidades e limitações do uso e cobertura da terra, auxiliando na elaboração de estratégias para o planejamento territorial eficiente.

A partir da avaliação das principais maneiras de ocupação da terra na área de estudo (agricultura e pastagem), relacionadas com as unidades de relevo, se espera que os sistemas de produção agrícola e pecuária sejam concebidos com o objetivo de apresentar um funcionamento com desempenho similar aos ecossistemas naturais, uma vez que, a manutenção da produtividade agrícola e pecuária, associado com a manutenção dos recursos naturais reduz significativamente os potenciais impactos ao meio ambiente.

A eficiência dos sistemas agrícolas e da pecuária, em curto e longo prazo, está associada ao arranjo das diversas formas do relevo, que influencia na ciclagem dos nutrientes, regulação do microclima e nos processos hidrológicos. Dessa forma, à medida que se utiliza o minímo de insumos artificiais externos aos sistemas de produção, ocorre o manejo adequado da matéria orgânica, água, vegetação, micro e mesofauna por meio dos mecanismos reguladores internos, além da capacidade de restabelecer seu equilíbrio após distúrbios causados pelo manejo e a colheita.

O planejamento das atividades de agricultura e pastagem requer uma visão integrada dos componentes da paisagem, em especial o relevo, no qual sistemas mais diversos possuem menor investimento de trabalho e insumo, devido as condições de terreno necessárias para manter a produtividade agrícola elevada. O manejo adequado desses sistemas de produção é, portanto, destinado a otimização dos processos de fluxo de nutrientes, conservação da superfície dos solos, conservação dos recursos naturais e manutenção da biodiversidade, que acarreta na eficiência da gestão dos recursos naturais e do planejamento territorial. 


\section{REFERÊNCIAS BIBLIOGRÁFICAS}

Ab'Sáber A. N. 1977. Os domínios morfoclimáticos na América do Sul: primeira aproximação. Geomorfologia, 52: 17-28.

Ab’Sáber A. N.1969. Geografia e planejamento. Revista de História, 39: 257-272.

Ab’Sáber A. N.1975. Formas de Relevo: Texto Básico. FUNBEC/Edart, São Paulo, 80 pp.

Ab'Sáber A.N., Costa Júnior, M. 1950. Contribuição ao estudo do Sudoeste Goiano. Boletim Paulista de Geografia, 2:3-26.

Albarede F. 2011. Geoquímica, uma introdução. Oficina de Textos, São Paulo.

Alho C. J. R., Martins E. S. 1995. De grão em grão, o Cerrado perde espaço (Cerrado Impactos do Processo de Ocupação). WWF- Fundo Mundial para a Natureza, Brasília.

Almeida L., Resende L., Rodrigues A.P., Campos J.E.G. 2006. Hidrogeologia do Estado de Goiás e Distrito Federal. SIEG, Goiás.

Anderson J.R., Hardy E.E., Roach J.T., Witmer R.E.A. 1976. Land Use and Land Cover Classification System For for Use use With with Remote Sensor Data. Geological Survey Professional Paper, 964.

Araújo Filho, M., Meneses P.R., Sano E.E. 2007. Sistema de classificação de uso e cobertura da terra com base na análise de imagens de satélite. Revista Brasileira de Cartografia, 59:171-179.

Arruda M. B., Proença C. E. B., Rodrigues S. C., Campos R. N., Martins R. C., Martins, E. S. 2008. Ecorregiões, unidades de conservação e representatividade ecológica do bioma Cerrado. In: S. M. Sano, S. P. Almeida, J. F. Ribeiro (Org.) Cerrado: ecologia e flora. Embrapa Cerrados, Brasília, p.:231-272.

Austin A. T., Bustamante M. M. C., Nardoto G. B., Mitre S. K., Pérez T., Ometto P. H. B., Ascarrunz N. L., Forti, M. C., Longo K., Gavito M. E., Enrich-Prast A., Martinelly L. A. 2013. Latinamerica's nitrogen challenge. Science, 340:149-150.

Bailey R. G.2005. Identifying ecoregion boundaries. Environmental management. 34: 1426.

Baran-Zgłobicka B., Zgłobicki W. 2012. Mosaic landscapes of SE Poland: should we preserve them? Agroforestry Systems, 85:351-365.

Barcellos A. O. 1996. Sistemas extensivos e semi-intensivos de produção: pecuária bovina de corte no Cerrado. In: Simpósio sobre o Cerrado, 8, e International Symposium on Tropical Savannas, 1, Anais..., p. 130-136.

Bertran P. 2000. História da terra e do homem no Planalto Central: eco-história do Distrito Federal do indígena ao colonizador. 1 ed. Instituto Bertran Fleury. Disponível em: http://www.paulobertran.com.br/bertran/historia.php. Acesso em: 20 ago. 2015.

Borges M. E. S., Carvalho Júnior O. A., Martins E. S., Arcoverde G. F. B., Gomes R. A. T. 2007. Emprego do processamento digital dos parâmetros morfométricos no mapeamento geomorfológico da bacia do Rio Preto. Espaço \& Geografia, 10 (2): 401-429.

Brasil A., Alvarenga S. 1989. Relevo. In: Duarte A. Geografia do Brasil: Região Centro Oeste. IBGE, Rio de Janeiro, p.: 53-72.

Brossard M., Barcellos A. O. 2005. Conversão do Cerrado em pastagens cultivadas e 
funcionamento dos Latossolos. Cadernos de Ciência \& Tecnologia, 22 (1): 153-168.

Carneiro M. A. C., Souza E. D., Paulino H. B., Sales L. E. O., Vilela L. A. F. 2013. Atributos indicadores de qualidade em solos de Cerrado no entorno do Parque Nacional das Emas, Goiás. Bioscience Journal, 29(6):1857-1868.

Casseti V. 2005. Geomorfologia [online]. Furnarpe, São Paulo. Disponível em: http://www.funape.org.br/geomorfologia. Acesso em: 20 Out. 2015.

Castro K.B., Martins E. S., Gomes M. P., Reatto A., Lopes C. A., Passo D. P., Lima L. A. S., Cardoso W. S., Carvalho Júnior O. A., Gomes R. A. T. 2010a. Caracterização Geomorfológica do Município Luís Eduardo Magalhães, Oeste Baiano, escala 1:100.000. Embrapa Cerrados, Brasília, 32pp. (Boletim de Pesquisa e Desenvolvimento, 288).

Castro K.B., Martins E. S., Gomes M. P., Reatto A., Passo D. P., Lima L. A. S., Carvalho Júnior O. A., Gomes R. A. T. 2010b. Caracterização Geomorfológica do Município Jaborandi, Oeste Baiano, escala 1:100.000. Embrapa Cerrados, Brasília, 33pp. (Boletim de Pesquisa e Desenvolvimento, 285).

CBH Paranaíba- Comitê da Bacia Hidrográfica do Rio Paranaíba. 2016. Potencialidades. Disponível em: http://cbhparanaiba.org.br/a-bacia/potencialidades. Acesso em: 10 Mar. 2016.

Christofoletti A. 1994. Aplicabilidade do Conhecimento Geomorfológico nos Projetos de Planejamento. In: Guerra A. T., Cunha S. B. (Org.). Geomorfologia: Uma atualização de bases e conceitos, 1 ed, Bertrand Brasil, Rio de Janeiro, p.: 415-441.

Copeland, J.H., Pielke, R.A., Kittel, T.G.F. 1996. Potential climate impacts of vegetation change: A regional modeling study. Journal of Geophysical Research, 101:7409-7418.

Couto Júnior A. F., Carvalho Júnior O. A., Martins, E. S., Souza V. V., Farias, M. F., Encinas J. M. 2007. Relação entre uso e ocupação do solo e os aspectos geomorfológicos no município de águas lindas de Goiás. Espaço \& Geografia, 10:125-141.

Dal' Bó P. F. F., Basilici G. 2011. Interpretação paleoambiental da formação Marília na porção noroeste da bacia Bauru: relações entre sedimentação e paleopedogênese em um antigo lençol de areia eólica. Geociências, 30(4): 509-528.

Dinerstein E., Olson D., Graham D., Primm S, Bookbinder, M., Ledec G. 1995. Una evaluación del estado de conservación de las ecorregiones terrestres de América Latina y el Caribe. WWF, Washington, $135 \mathrm{pp}$.

Ehsani A.H., Quiel F. 2008. Geomorphometric feature analysis using morphometric parameterization and artificial neural networks. Geomorphology, 99:1-12.

EIBH. Estudos Integrados de Bacias Hidrográficas. 2005. Estudos Integrados de Bacias Hidrográficas - Sudoeste do Estado de Goiás. Engevix, Brasília. (Pen Drive).

Eiten G. 1972. The Cerrado vegetation of Brazil. Botanical Review, 38:201-341.

Fernandes L. A. 1998. Estratigrafia e evolução geológica da parte oriental da Bacia Bauru (Ks, Brasil). Tese de Doutorado, Instituto de Geociências, Universidade de São Paulo, 216 p.

Fernandes L. A., Coimbra A. M. 1996. A Bacia Bauru (Cretáceo Superior, Brasil). Anais da Academia Brasileira Ciências, 68(2): 195 - 205.

Fernandes M. A., Carvalho I. S. 2008. Revisão diagnóstica para a icnoespécie de tetrápode Mesozóico Brasilichnium elusivum (Leonardi, 1981) (Mammalia) da Formação Botucatu, 
Bacia do Paraná, Brasil. Ameghiniana, 45 (1):167-173.

Ferreira L. G., Ferreira M. E., Rocha, G. F., Nemayer, M., Ferreira N. C. 2009. Dinâmica agrícola e desmatamentos em áreas de cerrado: uma analise a partir de dados censitários e imagens de resolução moderada. Revista Brasileira de Cartografia, 61(2):117-127.

Ferreira M. E., Ferreira L.G. Miziara F., Soares Filho B. S. 2013. Modeling landscape dynamics in the central Brazilian savanna biome: future scenarios and perspectives for conservation. Journal of Land Use Science, 8:403-421.

Guerra A. J. T., Pereira J. B. da S., Kassab M. M., Figueiredo P.R. H., Almeida V. J., Regis W. D. E. 1989. Um estudo do meio físico com fins de aplicação ao planejamento do uso agrícola da terra no Sudoeste de Goiás. IBGE, Rio de Janeiro, 210 pp. (Convênio IBGE/EMBRAPA).

Hermuche P.M., Guimarães R.F., Carvalho A.P.F., Martins E.S., Druck S., Carvalho Júnior O.A., Ferreira N.B. S., Reatto A. 2002. Morfometria como suporte para elaboração de mapas pedológicos: I. Bacias hidrográficas assimétricas. Embrapa Cerrados, Brasília. (Boletim de Pesquisa e Desenvolvimento).

Heymann Y., Steenmans C., Croisille G., Bossard M., Lenco M., Wyatt B., Weber J.-L., O’brian C., Cornaert M.-H., Sifakis N..1993. 'CORINE Land Cover: Technical Guide', Environment, nuclear safety and civil protection series, Commission of the European Communities, Office for Official Publications of Mapping urban heat islands 2315 the European Communities, Luxembourg, EUR 12585, 144 pp.

Hypolito R., Andrade, S., Ezaki S. 2011. Geoquímica da interação - água, rocha, solo estudos preliminares. All Print, Goiânia.

IBGE-Instituto Brasileiro de Geografia e Estatística. 1985. Manual de atualização cartográfica, IBGE, Rio de Janeiro, $32 \mathrm{pp}$.

IBGE-Instituto Brasileiro de Geografia e Estatística. 2006. Manual técnico de uso da terra. 1 ed., IBGE, Rio de Janeiro.

IBGE-Instituto Brasileiro de Geografia e Estatística. 2009. Manual técnico de geomorfologia. IBGE, Rio de Janeiro, 182 pp.

IBGE-Instituto Brasileiro de Pesquisa e Estatistica. 2010. Atlas nacional do Brasil, domínios morfoestruturais e morfoclimáticos - compartimentos do relevo. 1 ed., IBGE, Rio de Janeiro.

Ker J. C.1997. Latossolos do Brasil: Uma Revisão. Genomos, 5(1):17-40.

King L.C. 1956. A geomorfologia do Brasil Oriental. Revista Brasileira de Geografia, 18(2): 147-265.

Klink C. A., Machado R. B. 2005. A conservação do cerrado brasileiro. Megadiversidade, 1:147-155.

Lacerda Filho, J. V., Rezende, A., Silva, A. (Org). 1999. Programa Levantamentos Geológicos Básicos do Brasil. Geologia e Recursos Minerais do Estado de Goiás e Distrito Federal. CPRM, Goiânia, 200 pp.

Lambin E., Geist H., Lepers E. 2003. Dynamics of land-use and land-cover changes in tropical regions. Annual Review of Environment Resources, 28:205-241.

Lima L. A. S., Martins E. S., Gomes M. P., Reatto A., Lopes C. A., Xavier D. R., Passo D. 
P., Castro K. B., Carvalho Júnior O. A., Gomes R. A. T. 2010a. Caracterização geomorfológica do munícipio de Cocos, Oeste Baiano, escala 1:50.000. Embrapa Cerrados, Brasília, 30 pp. (Boletim de Pesquisa e Desenvolvimento, 284).

Lima L. A. S., Martins E. S., Reatto A., Castro K. B., Vasconcelos, V. S., Carvalho Júnior O. A. 2009. Caracterização geomorfológica e suas relações com solos na bacia do Alto do Rio Preto, GO. Embrapa Cerrados, Brasília, 24 pp. (Boletim de Pesquisa e Desenvolvimento, 255).

Machado R.B., Ramos Neto M.B, Pereira P.G.P., Caldas E.F., Gonçalves D.A., Santos N.S., Tabor K., Steininger M. 2004. Estimativas de perda da área do Cerrado brasileiro. Conservação Internacional, Brasília.

MACROZAEE-GO- Macrozoneamento Agroecológico e Econômico do Estado do Goiás. 2014a. Uso do Solo. ZAEE-GO, Goiás. Disponível em: < http://www.zee.go.gov.br/>. Acesso em: 14 Jul. 2015.

MACROZAEE-GO- Macrozoneamento Agroecológico e Econômico do Estado do Goiás. 2014b. Solo. ZAEE-GO, Goiás. Disponível em: < http://www.zee.go.gov.br/>. Acesso em: 14 Jul. 2015.

Martins E.S., Reatto A., Carvalho Junior O.A., Guimarães R.F. 2004. Evolução geomorfológica do Distrito Federal, escala 1:100.000. Embrapa Cerrados, Brasília, 57 pp. (Documentos, 122).

Mendes B. C. 2015. Mapeamento geomorfológico aplicado ao estudo do uso e cobertura da terra no Planalto Central. Dissertação de Mestrado, Instituto de Geociências, Universidade de Brasília, Brasília, 77p.

Meneses P. R. 2012. Modelos de cores aplicados às imagens. In: Meneses P.R., Almeida T. (Org). Introdução ao processamento de imagens de sensoriamento Remoto. 1 ed., CNPQ, Brasília, p.: 121-128.

Milani E. J., Thomaz Filho A. 2000. Sedimentary Basins of South America. In: Cordani U.G., Milani E.J., Thomaz Filho A., Campos D.A. Tectonic Evolution of South America. 31st International Geological Congress, p.: 389-449.

Miller K. 1997. Em busca de um novo equilíbrio: diretrizes para aumentar a oportunidades de conservação da biodiversidade por meio do planejamento biorregional. IBAMA, Brasília, 94 pp.

Oliveira C. 1988. Curso de Cartografia Moderna, 1 ed, IBGE, Rio de Janeiro.

Oliveira I. J. 2005. Os Chapadões de(s)cerrados: A vegetação o relevo e o uso das terras em Goiás e no Distrito Federal. In: Almeida M. G. (Org). Tantos Cerrados: múltiplas abordagens sobre a biodiversidade e singularidade cultural. Ed. Vieira, Goiânia.

Oliveira L. A., Campos J. E. G. 2012. Comportamento estrutural do Sistema Aquífero Guarani no estado de Goiás, Brasil. Revista da Sociedade Brasileira de Geologia, 42:128141.

Panquestor E. K., Carvalho Júnior O. A., Ramos V. M., Guimarães R. F., Martins E. S. 2004. Aplicação de indicadores quantitativos na definição de unidades de paisagem e uso da terra na bacia do rio Corrente-BA. In.: Encontro Nacional da Associação Nacional de Pós-Graduação e Pesquisa em Ambiente e Sociedade, 2, Anais..., p.1-16.

Passo D. P., Castro K. B., Martins E. S., Gomes M. P., Reatto A., Lima L. A. S., Carvalho Júnior O. A., Gomes R. A. T. 2010a. Caracterização geomorfológica do munícipio de São 
Desidério, BA, escala 1:50.000. Embrapa Cerrados, Brasília, 29 pp. (Boletim de Pesquisa e Desenvolvimento, 283).

Passo D. P., Martins E. S., Gomes M. P., Reatto A., Castro K. B., Lima L. A. S., Carvalho Júnior O. A., Gomes R. A. T. 2010b. Caracterização geomorfológica do munícipio de Barreiras, Oeste Baiano, escala 1:100.000. Embrapa Cerrados, Brasília, 31 pp. (Boletim de Pesquisa e Desenvolvimento, 294).

Passos E., Bigarella J. J. 2009. Superfícies de erosão. In: Cunha S. B., Guerra A. J. T. (Org.). Geomorfologia do Brasil. Bertrand Brasil, Rio de Janeiro, p.: 107-142.

Porto C. G.2009. Intemperismo em regiões tropicais. In: Guerra A. J. T., Cunha S. B. (Org.) Geomorfologia e meio ambiente. Bertrand Brasil, Rio de Janeiro, p.: 25-58.

Prado R. B., Ferreira C. E. G., Benites V. M, Naumoy A. 2009. Mapeamento e descrição do padrão de uso e cobertura da terra em municípios do sudoeste goiano a partir de imagens orbitais TM/Landsat-5. Embrapa Solos, Brasília. (Boletim de Pesquisa e Desenvolvimento)

Press F., Siever R., Grotzinger J., Jordan T. H. Tradução de Rualdo Menegat (Coord.). 2006. Para entender a Terra, Bookman, São Paulo, 656 pp.

Ratter J., Ribeiro J., Bridgewater S. 1997. The Brazilian Cerrado vegetation and threats to its biodiversity. Annals of Botany, 80:223-230.

Rawat J.S., Biswas V., Kumar M. 2013.Changes in land use/cover using geospatial techniques: A case study of Ramnagar town area, district Nainital, Uttarakhand, India. The Egyptian Journal of Remote Sensing and Space Sciences, 16:111-117.

Rezende G.C. 2003. Ocupação agrícola, estrutura agrária e mercado de trabalho rural no Cerrado: o papel do preço da terra, dos recursos naturais e das políticas públicas. In: Helfand S.M., Rezende G.C. (Eds). Região e espaço no desenvolvimento agrícola brasileiro, IPEA, Rio de Janeiro, p.: 173-212.

Ribeiro J. F., Walter B. M. T. 2008. As principais fitofisonomias do bioma Cerrado. In: Sano S. M., Almeida S. P., Ribeiro, J. F (Org.). Cerrado: ecologia e flora. Embrapa Cerrados, Brasília.

Richards J.A. 1999. Remote Sensing Digital Image Analysis, Springer-Verlag, Berlim.

Rohde G. M. 2013. Geoquímica ambiental e estudos de impacto. $4^{\mathrm{a}}$ Ed., Oficina de Textos São Paulo.

Rosa R. 2005. Geotecnologias na geografia aplicada. Revista do Departamento de Geografia, 16:81-90.

Ross J. L. S.2009. Geografia e as transformações da natureza: relação sociedade-natureza. In: Lemos A. I. G., Galvani E. (Org.). Geografia, tradições e perspectivas: Interdisciplinaridade, meio ambiente e representações. 1 ed., Expressão popular, p.: 119138.

Ross J.L.S. 1992. O registro cartográfico dos fatos geomórficos e a questão da taxonomia do relevo. Revista do Departamento de Geografia, FFLCH-USP, 6:17-29.

Sano E. E., Rosa R., Brito J. L. S., Ferreira L. G. 2008. Mapeamento semidetalhado do uso da terra do bioma Cerrado. Pesquisa Agropecuária Brasileira, 43: 153-156.

Sano E. E., Rosa R., Brito J. L. S., Ferreira L. G., Bezerra H. S. 2009. Mapeamento da 
cobertura vegetal natural e antrópica do bioma Cerrado por meio de imagens Landsat ETM+. In: SBSR, Simpósio Brasileiro de Sensoriamento remoto, 14, Anais, p. 1199.

Sano E.E., Barcellos A.O., Bezerra H.S. 2001. Assessing the spatial distribution of cultivated pastures in the Brazilian savana. Pasturas Tropicales, 22:2-15.

Sena-Souza J.P, Martins E. S., Couto Júnior A. F., Reatto A., Vasconcelos V., Gomes M. P., Carvalho Júnior O. A., Reis A.M. 2013. Mapeamento geomorfológico da bacia hidrográfica do Rio São Bartolomeu, escala 1:100.000. Embrapa Cerrados, Brasília, 38 pp. (Boletim de Pesquisa e Desenvolvimento $\mathrm{n}^{\circ}$ 314).

Silva E. B., Ferreira Júnior L. G., Anjos A. F., Miziara F. 2013a. Análise da distribuição espaço-temporal das pastagens cultivadas no bioma Cerrado entre 1970 e 2006. Revista IDeaAS, 7(1):174-209.

Silva E. B., Ferreira Júnior L. G., Anjos A. F., Miziara F. 2013b. A expansão da fronteira agrícola e a mudança de uso e cobertura da terra no centro-sul de Goiás, entre 1975 e 2010. Atêlie Geográfico, 7(2): 116-138.

Silva F.A.M, Assad E.D., Evangelista B.A. 2008. Caracterização climática do bioma Cerrado. In: Sano S. M., Almeida S. P., Ribeiro J. F. (Org). Cerrado: ecologia e flora, 2 ed. Embrapa Cerrados, Brasília.

Silva J. F., Fariñas M. R., Felfili J. M., Klink C. 2006. A. Spatial heterogeneity, land use and conservation in the Cerrado region of Brazil. Journal of Biogeography, 33:536-548.

Silva J., Bates J. 2002. Biogeographic patterns and conservation in the South American Cerrado: A tropical savanna hotspot. Bioscience, 52: 225-233.

Soares P. C., Landim P. M. B, Fúlfaro V. J., Sobreiro Neto, A. F. 1980. Ensaio de caracterização estratigráfica do Cretáceo no Estado de São Paulo: Grupo Bauru. Revista Brasileira de Geociências, 10(3):177-185.

Suguio K. 2000. Rochas sedimentares: propriedades, gênese, importância econômica. Edgard Blücher, São Paulo.

Teixeira W., Fairchild T. R., Toledo M. C. M., Taioli F. (Org.). 2009. Decifrando a Terra, Companhia Editora Nacional, São Paulo, 623 pp.

Valeriano M. M. 2008. Dados Topográficos: extração automática de variáveis morfométricas. In: Florenzano T.G. (Org). Geomorfologia: conceitos e tecnologias atuais. São Paulo, p.: 85- 91.

Wicander R., Monroe J. S. 2009. Fundamentos de geologia, Cengage Learning, São Paulo.

Wood J. 1996. The Geomorphological Characterization of Digital Elevation Models. Ph.D. Thesis, Department of Geography, University of Leicester.

Ximenes A. C., Amaral S., Valeriano D.M. 2009. O conceito de ecorregião e os métodos utilizados para o seu mapeamento. Geografia (Rio Claro), 35: 219-227.

Young M. 1978. Terrain analysis: program documentation. Report 5 on Grant DA-ERO591-73- G0040, Statistical characterization of altitude matrices by computer. Department of Geography, University of Durham, England. 27 pp. 